\title{
Identifying Pelagic Fish Eggs in the Southeast Yucatan Peninsula using DNA Barcodes
}

\begin{tabular}{|r|l|}
\hline Journal: & Genome \\
\hline Manuscript ID & gen-2015-0151.R2 \\
\hline Manuscript Type: & Article \\
\hline Date Submitted by the Author: & 04-Apr-2016 \\
\hline Complete List of Authors: & $\begin{array}{l}\text { Leyva-Cruz, Elva; El Colegio de la Frontera Sur, Ecología y Sistemática } \\
\text { Acuática } \\
\text { Vásquez-Yeomans, Lourdes; El Colegio de la Frontera Sur, Ecología y } \\
\text { Sistemática Acuática } \\
\text { Carrillo, Laura; El Colegio de la Frontera Sur, Ecología y Sistemática } \\
\text { Acuática } \\
\text { Valdez-Moreno, Martha; El Colegio de la Frontera Sur, Ecología y } \\
\text { Sistemática Acuática }\end{array}$ \\
\hline Keyword: & $\begin{array}{l}\text { Mesoamerican Reef, Fish spawning areas, Early fish stages, Fish egg } \\
\text { descriptions, BOLD database }\end{array}$ \\
\hline
\end{tabular}




\section{Identifying Pelagic Fish Eggs in the Southeast Yucatan Peninsula using DNA Barcodes}

E. Leyva-Cruz ${ }^{1}$, L. Vásquez-Yeomans ${ }^{1}$, L. Carrillo $^{1}$ and M. Valdez-Moreno ${ }^{1 *}$.

${ }^{1}$ Department of Systematic and Aquatic Ecology, El Colegio de la Frontera Sur Chetumal Unit, Centenario Avenue Km 5.5 Col. Pacto Obrero Campesino, Chetumal, Quintana Roo, Mexico, 77014.

*Corresponding author - email: mvaldez@ecosur.mx 


\section{Abstract}

In the waters surrounding Banco Chinchorro in the Mexican Caribbean are spawning and nursery areas for many types of fish. In this natural environment, as opposed to under controlled lab conditions, it is almost impossible to link an individual egg to the adult that laid it. This makes identifying the species of the eggs difficult. However, DNA barcodes have made this easier. In the present study, 300 eggs were processed for molecular analysis, from which 139 sequences were obtained. We identified 42 taxa (33 species with their binomial names), 35 genera, and 24 families. The identified eggs included those from Ariomma melanum, which is the first recording of this species in the Mexican Caribbean. Eggs from economically important fish species were also identified, including frigate tuna (Auxis thazard), crevalle jack (Caranx hippos), common dolphinfish (Coryphaena hippurus), sailfish (Istiophorus platypterus), white marlin (Kajikia albida), skipjack tuna (Katsuwonus pelamis), blackfin tuna (Thunnus atlanticus), and swordfish (Xiphias gladius). We have also described new morphological characteristics and captured photographs for 21 species, as well as obtained new information about spawning locality and time for 16 species. This valuable information will provide the basis to develop more effective conservation measures for sustainable fisheries and protection of the Mesoamerican Barrier Reef System.

Key words: Early fish stages; Mesoamerican Reef; Fish spawning areas; Fish egg descriptions, BOLD database. 


\section{Introduction}

The Mexican Caribbean lies within the Mesoamerican Barrier Reef System (MBRS), the second-largest reef in the world (Almada-Villela et al. 2003). This area provides a suitable habitat for many fish species, including jacks and bonefish (Perez-Cobb et al. 2014), snappers, and groupers (Graham et al. 2008; Heyman and Kjerfve 2008), all of which have both commercial and game value.

Overexploitation of fisheries and a decline in marine resources are global problems that require constant evaluation of the population dynamics of fish species (ArreguínSanchez and Arcos-Huitrón 2011). Several processes can influence the increase or decrease of fish populations, such as recruitment at different stages of the life cycle, dispersal, and retention of organisms (Gleason and Burton 2012; Cheng et al. 2013). In order to perform a detailed and reliable study of these phenomena, it is necessary to accurately identify specimens of these species at all stages of their life cycle (Richardson et al. 2007).

Morphological features that are routinely used to recognize adult fish species are not present at the early stages of development, making identification of younger fish more difficult. In the case of fish eggs, the most important characteristics used for identification are shape, size, perivitelline space, oil globules, inner membrane, chorion, embryo, yolk shape, and pigment pattern (Ahlstrom and Moser 1980; Matarese and Sandknop 1984).

Nevertheless, despite the limited number of diagnostic characters available for the identification of fish eggs, some progress has been made in obtaining descriptions and 
producing identification guides for the early developmental stages of fish around the world (Leis and Carson-Ewart 2000; Richards 2006; Fahay 2007). However, in most cases, these guides are incomplete. For example, in the Western Central Atlantic (WCA, FAO area 31), which includes the Yucatan Peninsula, there are approximately 2235 known fish species, but only $9 \%$ of them have an identifiable egg stage (Richards 2006). In fact, it is estimated that only $10 \%$ of the world's fish species have been documented from the early stages (Richards 1985; Kendall and Matarese 1994).

Molecular characters, such as DNA barcodes, have been successfully used to identify most animal species (Hebert et al. 2003), including fish from different regions worldwide (Ward et al. 2005; Hubert et al. 2008; Rock et al. 2008; Lara et al. 2010; Valdez-Moreno et al. 2010; Oliveira-Ribeiro et al. 2012). The idea of identifying the early stages of fish development with DNA barcoding was first proposed about eight years ago (Pegg et al. 2006), but since then, it has only been used in a few studies (Valdez-Moreno et al. 2010; Burghart et al. 2014).

For this reason, the aim of this study was to use morphology and DNA barcodes to identify fish eggs from the south-central part of the Mesoamerican Reef. Our data on the species richness and geographical distribution of the eggs will provide a strong basis for environmentalists and developers to establish a sustainable environment within this important region. 


\section{Materials and methods}

Sample collection and processing

Samples were collected during an oceanographic cruise supported by a collaborative effort between El Colegio de la Frontera Sur (ECOSUR), the National Oceanic and Atmospheric Administration (NOAA), and Miami University, and were processed on board the Research Vessel Gordon Gunter.

Sampling was conducted from the $20^{\text {th }}$ to the $22^{\text {nd }}$ of April 2011, from 17 offshore stations located in the waters surrounding the largest pseudo-atoll in the Caribbean, the Biosphere Reserve Banco Chinchorro (17 $\left.45^{\prime}-19^{\circ} 30^{\prime} \mathrm{N} 85^{\circ} 40^{\prime}-88^{\circ} 00^{\prime} \mathrm{W}\right)$. According to geographic coordinates, two stations ( 82 and 83 ) were in the Belize jurisdiction, and the remaining fifteen (78-81 and 84 to 95 , there is not number 92) were in Quintana Roo State, Yucatan Peninsula, Mexico (Fig. 1).

Two types of nets were used to collect the zooplankton: Neuston with a $0.947 \mathrm{~mm}$ mesh cloth size fitted on a $1 \times 2 \mathrm{~m}$ rectangular aluminum frame, and a new sampling implement, Spanish Neuston S-10 with a $0.505 \mathrm{~mm}$ mesh size fitted on a 1 x $2 \mathrm{~m}$ rectangular aluminum frame (Habtes et al. 2014). Tows conditions for both nets were: duration $10 \mathrm{~min}$, at a speed of two knots $(3.7 \mathrm{~m} / \mathrm{h})$. The neuston net was used at a depth 0.5 $\mathrm{m}$, and hence half of the frame was out of the water. Therefore, we cannot estimate the volume of filtered water. The Spanish Neuston net was used at $10 \mathrm{~m}$ depth. Samples were fixed in $96 \%$ ethanol, to replace the seawater. 


\section{Laboratory analyses}

Eggs were extracted from plankton samples, counted, and sorted under a stereomicroscope according to recognizable morphotypes. Observations were made using $4 \mathrm{x}, 5 \mathrm{x}$, and 10x magnifications. The main characteristics used were size, shape (spherical, ellipsoidal), width of the perivitelline space (narrow, wide, medium), presence or absence of oil globules, presence or absence of an inner membrane, pigmentation patterns and yolk characteristics (colour, segmentation), chorion (ornamentation, texture), and embryo (formation, pigments) (Ahlstrom and Moser 1980; Matarese and Sandknop 1984; Richards 2006).

Depending on the number of eggs available that displayed a particular morphotype, between one and five specimens per morphotype for each sampling station were selected for the DNA barcode analysis. Each specimen was transferred into water before photography to avoid drying during this process. All of the eggs were photographed using Nikon SMZ745T and Canon EOS Rebel T31 cameras, both of which were connected to a stereomicroscope. Between 100 and 250 photographs were stacked into one image using Helicon Focus 6.2.0 software (Kozub et al. 2008) to represent the entire egg. Once photographed, the eggs were placed in a 96-well plate for molecular analysis. All tools were flame sterilized before and after use with each sample to prevent contamination.

Extraction, amplification, and sequencing of the COI gene 
DNA extraction, amplification, and sequencing were performed according to published protocols (Valdez-Moreno 2010). Before DNA extraction, ethanol was evaporated at $56^{\circ} \mathrm{C}$. PCR amplification was performed in the barcode laboratory at ECOSUR (Chetumal). Fish primers used were Fish F1, Fish R1, Fish F2, and Fish R2 (Ward et al. 2005). Sequencing was performed using an M13-tailed fish primer-cocktail (Ivanova et al. 2007). Sequences were aligned using Codon Code 5.0.1 software. Primer details, trace files, and sequences are available under the project "Fish Eggs of the Caribbean" (code MXFEC) in the Barcode of Life Data Systems database (BOLD, www.boldsystems.org; Ratnasingham and Hebert 2007) and GenBank (http://www.ncbi.nlm.nih.gov).

\section{Data analysis}

Sequences were compared with previously published sequences in BOLD using the specimen identification tool provided in the system (Ratnasingham and Hebert 2007). Neighbor-Joining (NJ) trees (Saitou and Nei 1987) were constructed using pairwise genetic distances based upon the Kimura two-parameter model (K2P) (Kimura 1980) and pairwise deletion of missing data using MEGA 3 software (Kumar et al. 2004). Terminal nodes were collapsed to represent species-level groupings for visualization purposes. The height of each triangle represents the number of specimens sequenced while the depth represents the genetic diversity present within each cluster. BOLD also assigned a Barcode Index Number (BIN) to each specimen (see Ratnasingham and Hebert 2013). 
The criteria to obtain species-level identifications using the barcode database were as follows: specimens with $>98.4 \%$ sequence similarity to reference sequences and within the same BIN (Ratnasingham \& Hebert, 2013) were assigned a species-level identification. When the similarity values to reference sequences were between $95 \%$ and $98.3 \%$, eggs were assigned to genus, family, and order. When genetic similarity was $<95 \%$, specimens were considered unidentified.

Species richness of all sequenced eggs at each sampling station, as well as the distributions of the three most broadly distributed species, were mapped using ArcView GIS ${ }^{\mathrm{R}} 3.2$ software. For the richness values, we included those eggs identified to a Linnaean species as well as those eggs that were recognized as being likely separate species on the basis of the BIN criterion, but which currently lack a binomial.

\section{Results}

Species identification

A total of 1391 eggs was collected. All of them were recognized within 94 different morphotypes, but it was only possible to identify the species for 10 of them using morphology: Auxis thazard, Cheilopogon exsiliens, Gempylus serpens, Lachnolaimus maximus, Oxyporhamphus micropterus, Sparisoma viride, Diplospinus multistriatus, Lactoprhys trigonus, Synodus synodus, and Xiphias gladius. The remaining 84 morphotypes could not be assigned to a particular species on the basis of morphology. 
For the molecular analyses, we processed 300 eggs, which represented all of the morphotypes with at least one specimen (see methods). From these, we obtained 139 sequences, representing a $46.3 \%$ sequencing success rate. Sequence length ranged from 188 to 665 base pairs (bp). Short sequences were used as mini-barcodes for identification (sensu Meusnier et al. 2008). No insertions, deletions, or stop codons were observed. The average K2P distance between barcode sequences within species was $0.64 \%$, whereas interespecific divergences among species within genera 13.3\%. All species, except for the bigeye (Priacanthus arenatus) (451 bp) and Peristedion sp. (265 bp), were assigned to a BIN number (Ratnasingham and Hebert 2013) within the BOLD system (Fig. S1). ${ }^{1}$ DNA sequences have been submitted to GenBank (Accession No. KR086792-KR086931).

Of the 139 sequences, $85.7 \%$ matched sequences in the BOLD reference library with $>98.4 \%$ similarity, allowing for species-level identification (Ratnasingham and Hebert 2013). The remaining $14.3 \%$ could be identified at only the genus, family, or order level. Seven orders, 24 families, 35 genera, and 42 taxa (33 species with their binomial names) were identified (see project "Fish Eggs of the Caribbean" (code MXFEC) in www.boldsystems.org). The families with the most species were Gempylidae and Stomiidae (four species), followed by Carangidae, Scombridae, and Synodontidae (each with three); Bramidae, Coryphaenidae, and Istiophoridae (two species each); and Acropomatidae, Ariommmidae, Diodontidae, Echeneidae, Exocoetidae, Lampridae,

\footnotetext{
${ }^{1}$ Fig.S1. Full neighbor-joining tree based on genetic distances (K2P) from the COI gene, with their respective name and BIN.
} 
Lophotidae, Ostraciidae, Peristediidae, Priacanthidae, Regalecidae, Sparidae, Trachipteridae, Trichiuridae, and Xiphiidae (one species each) (Fig. 2).

Sixteen eggs were identified only at the genus level: Benthodesmus, Brama, Chauliodus, Decapterus, Leptostomias, Peristedion, and Trachipterus; one egg was identified as belonging to the family Exocoetidae, and four were identified as belonging to the order Perciformes.

New observations on morphological features of the eggs

All species displayed a spherical-shaped egg, although the morphology in some cases was damaged during collection and storage. Egg diameters ranged from $0.4 \mathrm{~mm}$ to $2.1 \mathrm{~mm}$, which falls within the range that had been previously reported for marine fish $(0.5-$ $5.5 \mathrm{~mm}$ ) (Ahlstrom and Moser 1980; Matarese and Sandknop 1984). The smallest eggs were from Sailfish (Istiophorus platypterus), and the largest were from Giant oarfish (Regalecus glesne) and Chauliodus sp. Most of the eggs were smaller than those reported in the literature (Richards 2006; Fahay 2007); however, this was likely due to slight dehydration of the specimen from the alcohol fixation, because the diameter increased slightly when the eggs were introduced into water. 
Here, we report the first morphological descriptions of egg stages for twenty-one different species. The number of individuals analyzed, diameter of the eggs, and all characteristics are summarized in Table 1 (images are available in Fig. S2-S8). ${ }^{2}$

The morphologies of the remaining twelve species reported here have been described previously (Richards, 2006; Fahay, 2007), although we did observe some differences. We could not find oil globules in the eggs of frigate tuna (Auxis thazard), pompano dolphinfish (Coryphaena equiselis), common dolphinfish (Coryphaena hippurus), sailfish (I. platypterus), and skipjack tuna (Katsuwonus pelamis), but it is likely that they were dissolved during alcohol fixation and storage. An intussusception in the chorion was observed in the eggs of I. platypterus and K. pelamis (for a summary of dissimilarities, see Fig. S9). ${ }^{3}$

${ }^{2}$ Fig. S2. Photographs of unknown egg stages of Calamus calamus (A, B, C), Caranx hippos (D), Chauliodus danae (E), Decapterus punctatus (F).

Fig. S3. Photographs of unknown egg stages of Diplospinus multistriatus (A, B, C), Gempylus serpens (D), Kajikia albida (E, F).

Fig. S4. Photographs of unknown egg stages of Lactophrys trigonus (A, B, C), Nesiarchus nasutus (D, E, F).

Fig. S5. Photographs of unknown egg stages of Priacanthus arenatus (A, B), Prognichthys occidentalis (C), Promethichthys prometheus (D, E, F).

Fig. S6. Photographs of unknown egg stages of Pterycombus brama (A, B, C), Remora osteochir (D, E).

Fig. S7. Photographs of unknown egg stages of Saurida normani (A), Scombrolabrax heterolepis (B), Synagrops bellus (C) and Synodus synodus (D, E, F).

Fig. S8. Photographs of unknown egg stages of Thunnus atlanticus (A), Trachinotus falcatus (B, C) and Ariomma melanum (D).

${ }^{3}$ Fig. S9. Differences from previous descriptions are highlighted for Auxis thazard, Coryphaena equiselis, Coryphaena hippurus, Istiophorus platypterus, and Katsuwonus pelamis. 
The eggs of Sloane's viperfish Chauliodus sloani lacked the double membrane and narrow perivitelline space that had been previously reported (Fahay 2007); in fact, these had been reported as having a wide perivitelline space (Ahlstrom and Moser 1980; Matarese and Sandknop 1984). No tiny spines were observed in eggs from the crested oarfish (Lophotus lacepede). Oil globules and pigments were not observed in the eggs of $R$. glesne, possibly because they were unfertilized. In contrast, we observed small projections in the chorion, as reported by Kawakami and Aoyama (2010). The eggs of the sand diver (Synodus intermedius) did not have a sculptured chorion, and we observed pigmentation in the embryo head (Fig. S10). ${ }^{4}$

It is possible that we were able to observe more detailed characteristics than had previously been reported because we performed our analyses at higher magnifications. Here, we used $4 x, 5 x$, and 10x magnification, whereas the original descriptions did not indicate the magnifications at which the observations were made.

\section{Egg richness}

Stations located near to Chinchorro Bank contained the highest richest of eggs: station 91 had ten taxa, followed by stations 88 and 90 , which both had nine taxa. The southern stations $(78,81$ and 82$)$ located north of Belize contained the fewest, with only three taxa in each one (Fig. 3).

${ }^{4}$ Fig. S10. Differences from previous descriptions are highlighted for Chauliodus sloani, Lophotus lacepede, Regalecus glesne and Synodus intermedius. 
The most broadly distributed species were Diplospinus multistritus and R. glesne, which were found in eight stations each, followed by $N$. nasutus, which was found in six stations. The eggs of $D$. multistriatus were present in the south and central stations; $R$. glesne was recorded in the north and central stations; and N. nasutus was more common in the southernmost stations (Fig. 4).

\section{Discussion}

In the current study, we used the mitochondrial COI gene to identify a number of species from fish eggs (42 taxa), more than was found in previous reports. Burghart et al. (2014) found 14 taxa, from Terra Ceia Bay in Florida. When other genetic markers were used, a smaller number of species was found. For example, sixteen species were identified from 2698 eggs from the Mariana Islands using 16S ribosomal RNA (Kawakami et al. 2010), and five species were recognized from 52 eggs using a shorter version of $16 \mathrm{~S}$ ribosomal RNA (Saitoh et al. 2008). Other work has focused on the identification of particular species; for example, Hyde et al. (2005) recognized six species: swordfish (Xiphias gladius), shortbill spearfish (Tetrapturus angustirostris), common dolphinfish (Coryphaena hippurus), wahoo (Acanthocybium solandri), blue marlin (Makaira nigricans) and pompano dolphinfish (Coryphaena equiselis), and Carreon-Martínez (2010) recognized four species: (Menticirrhus americanus, Menticirrhus littoralis, Pogonias cromis and Sciaenops ocellatus) from the family Sciaenidae 
When we compared the barcodes (42 taxa as determined using the BOLD system tools) against the morphology (10 taxa morphologically identified to a Linnaean species name), only four species were the same: $X$. gladius, D. multistriatus, $A$. thazard, and $S$. synodus.

Of the ninety-four morphotypes that we identified, thirty two did not have sequence. Thirty could be grouped into ten species. This means that $K$. albida, K. pelamis, and $R$. osteochir each were comprised of four morphotypes; D multistriatus was represented by six morphotypes; and A. thazard, C. sloani, C. equiselis, I. platypterus, N. nasutus, and Leptostomias sp. each contained two morphotypes. The different morphotypes within species each represented a different stage of development of the same species. The remaining thirty-two morphotypes were species represented by only one stage (or morphotype), giving a total of 42 taxa that were recognized by the DNA barcodes. These results confirm the value of this technique for the identification of fish eggs.

In this work, we reported a $46.6 \%$ success rate in sequencing. This reflects the added difficulties in obtaining amplicons from eggs, as opposed to adults or larvae. These problems could be caused by several possible factors, such as poor fixation, storage time, egg handling, or the presence of oil globules that could interfere with the polymerase chain reaction. The exact cause will require further investigation.

Of the 33Linnaean species reported here, there were no existing data about the early developmental stages in the Mexican Caribbean for nine species: C. danae, C. sloani, D. multistriatus, L. guttatus, L. lacepede, P. occidentalis, P. prometheus, R. osteochir, and 
Synagrops bellus (Schmitter-Soto et al. 2000; Lavett 2003; Valdez-Moreno et al. 2010; Muhling et al. 2013).

The eggs that were identified as belonging to Benthodesmus using the BOLD system showed 100\% sequence identity to Simony's frostfish (B. simony), elongate frostfish (B. elongates), and slender frostfish (B. tenuis). The latter is the only species that had been previously recorded in the Western Central Atlantic (WCA) (Carpenter 2002). Recently, however, B. simonyi was recorded from Panama, Nicaragua, Portugal, and one larva was collected from near Punta Allen, Quintana Roo, as determined using sequences from BOLD (Valdez-Moreno et al. 2010). The confusion with the taxonomy of these three species means that at present, it is not possible to assign these eggs to any species, and doing so will require a more detailed analysis of the entire genus.

A similar situation exists with Brama eggs that matched two different taxa (with $98.89 \%$ similarity or more), bigtooth pomfret (B. orcini) and lesser bream (B. dussumieri). The latter is distributed in the WCA (Carpenter 2002). Furthermore, while it was also recently recorded in BOLD for the Mexican Caribbean, these sequences came from larvae not adults; therefore, identification of individuals using these data may not be reliable.

One egg, identified as the driftfish (Ariomma melanum), was found at station 90, close to Mahahual. In 2006, we barcoded a larva (MFLVI3570) from this species collected from an area close to Isla Mujeres, north of the Yucatan Peninsula, confirming the presence of this fish in this area (see project "Fish larvae of Mexico VI" in www.boldsystems.org. 
A. melanum is listed as having been identified in the Western Atlantic from New York, the northern Gulf of Mexico to Panama (Robins and Ray 1986), extending up to Uruguay (Figueiredo et al. 2002).Although its presence is expected in the Mexican Caribbean, it not has been reported here before, and thus our work presents a new record for this region. The discovery of this egg suggests that the south of the Mexican Caribbean was once a spawning area for this species.

Eggs identified as belonging to Decapterus matched the species mackerel scad ( $D$. macarellus) (99.54-100\%) and roughear scad (D. tabl) (99.54-99.69\%). However, in order to establish their correct taxonomic identity, it will be necessary to review all the specimens from both species in more detail.

Three specimens were identified as belonging to the genus Leptostomias. Twelve Leptostomias species have currently been reported worldwide (Froese and Pauly 2014). In BOLD, there are sequences for scaleless dragonfish (L. gladiator, L. longibarba), and nine more specimens not identified to species level. Six species are known to exist in the WCA: L. gladiator, L. longibarba, L. analis, L. bermudensis, L. bilobatus, and L. haplocaulus (Carpenter 2002). Our specimens most likely belong to one of the latter four that still have no sequence.

To date, twenty-three species of Peristedion have been described (Froese and Pauly 2014); eleven are distributed in the WCA (Carpenter 2002), seven of which are represented in BOLD. The remaining four, longnose armored searobin ( $P$. antillarum) and flathead 
searobin ( $P$. brevirostre, $P$. longispatha, and $P$. unicuspis), are not present in the database, and therefore, our sequence could belong to one of these species.

The Trachipterus egg showed sequence identity with dealfish (T. arcticus) and blackflash ribbonfish (T. jacksonensi) (with 98.4-99.8\% similarity). The latter is distributed in the WCA (Carpenter 2002), Western Indian Ocean, Southern Australia, Southwest Pacific, and Southwest Atlantic: Brazil and Argentina (Froese and Pauly 2014; Robins and Ray 1986; Ward et al. 2008). The former is distributed in the Northeast Atlantic. According to Fish Base, the Western Atlantic populations are most likely to be a separate species (Froese and Pauly 2014). For this reason, we were only able to assign our sample to a genus.

We found six eggs belonging to Chauliodus. After barcode analysis, they could be divided into two groups with greater than $3 \%$ divergence. The first group comprised five eggs (MXFEC52, MXFEC95, MXFEC183, MXFEC110, and MXFEC201) that were identified as C. sloani. The second group, represented by a single specimen (MXFEC022), was identified as Chauliodus sp. The species $C$. sloani is broadly distributed, and BOLD data indicate 16 published records are forming three BINs. These findings indicate that there are more than one species of Chauliodus, which was not previously known.

Five species were identified at the egg stage, all of which were previously identified in MBRS (Valdez-Moreno et al. 2010): yellow jack (Carangoides bartholomaei), white grunt (Haemulon plumierii), hogfish (Lachnolaimus maximus), flathead grey mullet (Mugil cephalus), and ocean surgeon (Acanthurus bahianus). These species, plus the 33 species 
reported here, making a total of 38 species, were confirmed by DNA barcoding to spawn in the Mexican Caribbean and surrounding waters. This represents approximately $6.7 \%$ of the 552 fish species reported in this area (Schmitter-Soto et al. 2000).

At the time of collection, some eggs were unfertilized, and others were fertilized. The majority were approximately at the same developmental stage, except for three species, $K$. albida (Fig. S11) ${ }^{5}$, K. pelamis (Fig. S12) ${ }^{6}$, and R. osteochir (Fig. S13) ${ }^{7}$. For these species, we observed differences in embryo morphology, as well as the tone and distribution of pigments, between the different stages.

We recorded the developmental stage of these three species, as well as the day of collection and the station from which the eggs were collected. We found that the less-developed stages were found in the southern stations $(78,79,82$ and 83$)$, whereas the most-developed stages were found in the northern stations (90, 93 and 95). We were able to draw some interesting conclusions from these data. First, it seems likely that spawning occurred in Belizean waters, and the eggs were transported northward by strong currents in this area (Muhling et al. 2013; Carrillo et al. 2015). Another possibility is that the spawning zones were in the coastal area of Xcalak and the vicinity of Banco Chinchorro, where spawning aggregations sites have been documented (Aguilar-Perera and Aguilar-Dávila 1996; Sosa et

\footnotetext{
${ }^{5}$ Fig. S11. Photographs showing differences in the morphology of eggs Kajikia albida collected from different stations.
}

${ }^{6}$ Fig. S12. Photographs showing differences in the morphology of eggs of Katsuwonus pelamis collected from different stations.

${ }^{7}$ Fig. S13. Photographs showing differences in the morphology of Remora osteochir collected from different stations. 
al. 2009). In both cases, egg hatching most likely would occur in the northern part of the Yucatan Peninsula. The timing of egg release and the likely trajectories caused by the currents is outside the scope of the present work; however, it would be an interesting subject for future investigation.

New information about spawning locality and time was obtained from egg records (see www.boldsystems.org) for saucereye porgy (Calamus calamus), dana viperfish (Chauliodus danae, C. sloani, D. multistriatus), snake mackerel (Gempylus serpens), buffalo trunkfish (Lactophrys trigonus), opah (Lampris guttatus, L. lacepede, N. nasutus, P. arenatus), bluntnose flyingfish (Prognichthys occidentalis), roudi escolar (Promethichthys prometheus), Atlantic fanfish (Pterycombus brama), marlin sucker (Remora osteochir), short jaw lizardfish (Saurida normani), and diamond lizardfish (Synodus synodus).

These data are critical for the protection of nurseries and spawning areas, especially for species of economic or game value (Richards 1985; Kawakami et al. 2010; Gleason and Burton 2012), such as A. thazard, Caranx hippos, C. hippurus, I. platypterus, Kajikia albida, K. pelamis, Thunnus atlanticus, and Xiphias gladius (Herrera-Pavon 2011; Muhling et al. 2013; Perez-Cobb 2014). This information is important because if we take into account the fact that most eggs remain in the water column for less than 24-48 hours after spawning (Richards et al. 2006), we will have a better idea about the closed seasons for these species. Nonetheless, further studies will be required to determine if these fish spawn during more than one season of the year. 
The sampling area used in the present study is influenced by the Caribbean circulation system (Muhling et al. 2013; Carrillo et al. 2015), and it has been suggested that there may be connectivity among all the MBRS (Muhling et al. 2013; Heyman and Kjerfve 2008). Therefore, the presence of eggs from species that had not previously been recorded in this region could be caused either by advection from currents or by adults migrating to these places to spawn. Deeper and more systematic oceanographic studies will be required to track the course of the eggs.

Our results provide fundamental evidence for fisheries management, allowing for more focus on conservation efforts in breeding areas. The information on egg distribution and possible spawning time will contribute to dispersal and connectivity studies that will support the sustainable use of the Mesoamerican Reef System. This information is crucial because these species could be more vulnerable at early developmental stages than at other stages, something that should be tested with more fieldwork and continuing research in the area.

Finally, it is important to mention that these types of studies will reduce the complexity of laboratory work as it would no longer be necessary to reproduce natural conditions to hatch eggs and rear larvae to identifiable stages.

\section{Acknowledgments}

We thank José Angel Cohuo Colli for his help with photo documentation, and the staff of ECOSUR, especially Selene Morales. The authors also thank the captain and crew of the NOAA ship Gordon Gunter. J. Lamkin kindly allowed us to participate in the project 
"Larval fish and physical oceanography survey of the Mesoamerican reef system." This contribution is part of the thesis requirements of the first author in the ECOSUR graduate program. The DNA samples were extracted and amplified in the barcodes laboratory at Chetumal by Arely Martinez Arce under the frame of the MEXBOL network. DNA sequencing was performed at the Biodiversity Institute of Ontario (BIO) and the Instituto de Biología de la Universidad Nacional Autónoma de México (IBUNAM). Sheila Morrell kindly reviewed the final English version of the manuscript. 


\section{References}

Aguilar-Perera, A., and Aguilar-Dávila, W. 1996. A spawning aggregation of Nassau grouper Epinephelus striatus (Pisces: Serranidae) in the Mexican Caribbean. Environ. Biol. Fish. 45: 351-361. Available from http://academic.uprm.edu/ mvpizzini/MVP/HTMLobj-217/Aguilar-PereraandAguilarDavila 1996.pdf [accessed 21 October 2015].

Ahlstrom, E.H., and Moser, H.G. 1980. Characters useful in identification of pelagic marine fish eggs. California Cooperative Oceanic Fisheries Investigations Report XXI. 121: 121-131, La Jolla, Califonia. Available from http://www.calcofi.org/publications/calcofireports/v21/CalCOFI_Rpt_Vol_21_1980.pd $\underline{\mathrm{f}}$ [accessed 21 October 2015].

Almada-Villela, P.C., Sale, P.F., Gold-Bouchot, G., and Kjerfve, B. 2003. Manual de métodos para el programa de monitoreo sinóptico del SAM. Proyecto para el Sistema Arrecifal Mesoamericano $\quad[$ on line $]$ Available from http://citeseerx.ist.psu.edu/viewdoc/download?doi=10.1.1.473.8134\&rep=rep1\&type= pdf [accessed 02 July 2015].

Arreguín-Sánchez, F., and Arcos-Huitrón, E. 2011. La pesca en México: estado de explotación y uso de los ecosistemas. Hidrobiológica. 21(3): 431-462. Available from http://investigacion.izt.uam.mx/rehb/publicaciones/21-3PDF/435-462 Arcos.pdf [accessed 21 October 2015]. 
Burghart, S.E., Van-Woudenberg, L., Daniels, C.A., Meyers, S.D., Peebles, E.B., and Breitbart, M. 2014. Disparity between planktonic fish egg and larval communities as indicated by DNA barcoding. Marine Ecol. Prog. Ser. 503: 195-204. Available from http://www.int-res.com/articles/meps oa/m503p195.pdf [accessed 21 October 2015].

Carpenter, K.E. 2002. The living marine resources of the Western Central Atlantic. Volume 2: Bony fishes part 1 (Acipenseridae to Grammatidae). FAO Species Identification Guide for Fishery Purposes and American Society of Ichthyologists and Herpetologists Especial Publication No. 5. Food and Agriculture Organization. Roma.

Carreon-Martinez, L., Holt, S.A., Scott-Nunez, B., Faulk, C.K., and Holt, G.J. 2010. The use of polymerase chain reaction for the identification of sciaenid eggs. Marine Biol. 157: 1889-1895. Available from http://link.springer.com/article/10.1007/s00227-0101441-5 [accessed 21 October 2015].

Carrillo, L., Johns, E.M., Smith, R.H., Lamkin, J.T., and Largier, J.L. 2015. Pathways and hydrography in the Mesoamerican Barrier Reef System: Part 1 Circulation [online]. Cont. Shelf $\quad$ Res. 109: 164-176. Available from http://www.aoml.noaa.gov/phod/docs/Carrillo_etal_CSR_2015a.pdf [accessed 22 October 2015].

Cheng, F., Li, W., Wu, Q. J., Murphy, B.R., and Xie, S.G. 2013. MOTU analysis of ichthyoplankton biodiversity in the upper Yangtze River, China. J. Appl. Ichthyol. 29: 
872-876. Available from http://onlinelibrary.wiley.com/doi/10.1111/jai.12207/pdf [accessed 21 October 2015].

Fahay, M.P. 2007. Early Stages of Fishes in the Western North Atlantic Ocean (Davis Strait, Southern Greenland and Flemish Cap to Cape Hatteras). Volume 1 and 2. Northwest Atlantic Fisheries Organization. Nova Scotia.

Figueiredo, J.L., Dos Santos de A. P., Yamaguti, N., Bernardes, R. A., and Del Bianco Rossi-Wongtschowski, C. L. 2002. Peixes da zona econômica exclusiva da Região Sudeste-Sul do Brasil: Levantamento com Rede de Meia-Água. São-Paulo: Editora da Universidade de São Paulo; Imprensa Oficial do Estado.

Froese, R., and Pauly, D. 2014. FishBase [on line]. Available from www.fishbase.org [accessed 30 June 2015].

Gleason, L.U., and Burton, R.S. 2012. High-throughput molecular identification of fish eggs using multiplex suspension bead arrays. Mol. Ecol. Res. 12: 57-66. Available from $\quad$ http://onlinelibrary.wiley.com/doi/10.1111/j.1755-0998.2011.03059.x/pdf [accessed 21 October 2015].

Graham, R.T., Carcamo, R., Rodhes K.L., Roberts, C.M. and Requena, N. 2008. Historical and contemporary evidence of a mutton snapper (Lutjanus analis Cuvier, 1828) spawning aggregation fishery in decline. Coral Reef. 27: 311-319. 
Habtes, S., Muller-Karger, F.E. Roffer, M.A., Lamkin, J.T., and Muhling, B. 2014. A comparison of sampling methods for larvae of medium and large epipelagic fish species during spring SEAMAP ichthyoplankton surveys in the Gulf of Mexico. Limnol. Oceanogr. Methods. 12, 2014, 86-101.

Hebert, P.D.N., Ratnasingham, S., and deWaard, J.R. 2003. Barcoding animal life: cytochrome c oxidase subunit 1 divergences among closely related species. Proc. $\begin{array}{lllll}\text { Royal } & \text { Soc. } & \text { 270: } & \text { S96-S99. } & \text { Available }\end{array}$ http://www.ncbi.nlm.nih.gov/pmc/articles/PMC1698023/pdf/12952648.pdf [accessed 21 October 2015].

Herrera-Pavon, R.L. 2011. Pesca deportivo-recreativa. In Riqueza biológica de Quintana Roo un análisis para su conservación. Tomo 1. Edited by C. Pozo, N. Armijo-Canto and S. Calmé. El Colegio de la Frontera Sur (ECOSUR), Comisión Nacional para el Conocimiento y Uso de la Biodiversidad (CONABIO), Gobierno del Estado de Quintana Roo y Programa de Pequeñas Donaciones (PPD), Distrito Federal, pp. 190_ 193.

Heyman, W.D., and Kjerfve, B. 2008. Characterization of transient multi-species reef fish spawning aggregations at Gladden Spit. Bull. Marine Sci. 83: 531-551.

Hubert, N., Hanner, R., Holm, E., Mandrak, N.E, Taylor E, Burridge M., Watkinson, D., Dumont, P., Curry, A., Bentzen, P., Zhang, J., April, J., and Bernatchez, L. 2008. 
Identifying Canadian Freshwater Fishes through DNA barcodes [online]. PLoS ONE. 3(6): e2490. doi: 10.1371/journal.pone.0002490.

Hyde, J.R., Lynn, E., Humphreys, J.R., Musyl, M., West, A.P., and Vetter, R. 2005. Shipboard identification of fish eggs and larvae by multiplex PCR, and description of fertilized eggs of blue marlin, short bill spearfish, and wahoo. Marine Ecol. Prog. Ser. 286: 269-277. Available from http://konatournaments.com/science/eggs.pdf [accessed 21 October 2015].

Ivanova, N.V., Zemlak, T.S., Hanner, R.H., and Hebert, P.D.N. 2007. Universal primer cocktails for fish DNA barcoding. Mol. Ecol. Notes. 7: 544-548. Available from http://onlinelibrary.wiley.com/doi/10.1111/j.1471-8286.2007.01748.x/pdf [accessed 21 October 2015].

Kawakami, T., Aoyama, J., and Tsukamoto, K. 2010. Morphology of pelagic fish eggs identified using mitochondrial DNA and their distribution in waters west of the Mariana Islands. Environ. Biol. Fishes. 87: 221-235. http://link.springer.com/article/10.1007\%2Fs 10641-010-9592-2\#/page-1 [accessed 21 October 2015].

Kendall, A.W., and Matarese, A.C. 1994. Status of early life history descriptions of marine teleosts. Fish. Bull. 92: 725-736. Available from http://fishbull.noaa.gov/924/kendall.pdf [accessed 21 October 2015]. 
Kimura M. 1980. A simple method of estimating evolutionary rate of base substitutions through comparative studies. J. Mol. Evol. 16: 11-120. Available from http://eclass.uoa.gr/modules/document/file.php/D473/\%CE $\% 92 \% \mathrm{CE} \% \mathrm{~B} 9 \% \mathrm{CE} \%$ B2\%CE $\% \mathrm{BB} \% \mathrm{CE} \% \mathrm{~B} 9 \% \mathrm{CE} \% \mathrm{BF} \% \mathrm{CE} \% \mathrm{~B} 3 \% \mathrm{CF} \% 81 \% \mathrm{CE} \% \mathrm{~B} 1 \% \mathrm{CF} \% 86 \% \mathrm{CE} \% \mathrm{AF} \%$ CE\%B1/Phylogeny/Kimura 1980.pdf [accessed 21 October 2015].

Kozub, D., Khmelik, V., Shapoval, J., Chentsov, V., and Yatsenko, S. 2008. Helicon Focus Pro. Kharkov: Helicon Soft Ltd. Available from http://www.heliconsoft.com/heliconsoft-products/helicon-focus/ [accessed 21 October 2015].

Kumar, S., Tamura, K., and Masatoshi, N. 2004. MEGA3: Integrated Software for Molecular Evolutionary Genetics Analysis and Sequence Alignment. Brief. Bioinform. 5: 150-163. Available from http://www.kumarlab.net/pdf_new/KumarTamura03.pdf [accessed 21 October 2015].

Lara, A., Ponce de León, J.L., Rodríguez, R., Casane, D., Coté, G., Bernatchez, L., and García-Machado, E. 2010. DNA barcoding of Cuban freshwater fishes: evidence for cryptic species and taxonomic conflicts. Mol. Ecol. Res. 10: 421-430. Available from http://onlinelibrary.wiley.com/doi/10.1111/j.1755-0998.2009.02785.x/pdf [accessed 21 October 2015].

Lavett, C., Tyler, J.C., Davis, W.P., Jones, R.S., Smith, D.G., and Baldwin, C.C. 2003. Fishes of the Pelican Cays, Belize. Atoll Res. Bull. 497: 1-88. Available from 
http://www.sil.si.edu/digitalcollections/atollresearchbulletin/issues/00497.pdf [accessed 22 October 2015].

Leis, J.M., and Carson-Ewart, B.M. 2000. The larvae of Indo-Pacific coastal fishes: An identification guide to marine fish larvae. Fauna Malesiana Handbook 2. Brill, Leiden, The Netherlands.

Matarese, A.C., and Sandknop, E.M. 1984. Identification of fish eggs. In Ontogeny and systematics of fishes. Edited by H.G. Moser, W.J. Richards, D.M. Cohen, M.P. Fahay, A.W. Jr. Kendall and S.L. Richardson. American Society of Ichthyologists and Herpetologists. Special Publication 1. pp. 27-31.

Meusnier, I., Singer, G.A.C., Landry, J.F., Hickey, D.A., Hebert, P.D.N., and Hajibabaei, M. 2008. A universal DNA mini-barcode for biodiversity analysis [online]. BMC Genom. 9: 214. Available from http://www.biomedcentral.com/content/pdf/14712164-9-214.pdf [accessed 22 October 2015].

Muhling, B.A., Smith, R.H., Vásquez-Yeomans, L., Lamkin, J.T., Johns, E.M., Carrillo, L., Sosa-Cordero, E., and Malca, E. 2013. Larval fish assemblages and mesoscale oceanographic structure along the Mesoamerican Barrier Reef System. Fish. Oceanogr. 22(5): 409-428. doi: 10.1111/fog.12031.

Oliveira-Ribeiro, A., Antunes-Caires, R., Casagrande-Mariguela, T., Garcia-Pereira, L.H., Hanner, R., and Oliveira, C. 2012. DNA barcodes identify marine fishes of Sao Paulo 
State, Brazil. Mol. Ecol. Res. 12: 1012-1020. Available from http://onlinelibrary.wiley.com/doi/10.1111/1755-0998.12007/pdf [accessed 22 October 2015].

Pegg, G.G., Sinclair, B., Briskey, L., and Aspden, W.J. 2006. MtDNA barcode identification of fish larvae in the southern Great Barrier Reef, Australia. Scientia $\begin{array}{llll}\text { Marina. } & 70(2): & \text { Available } & \text { from }\end{array}$ http://scientiamarina.revistas.csic.es/index.php/scientiamarina/article/viewFile/163/160 [accessed 22 October 2015].

Perez-Cobb, A.U., Arce-Ibarra, A.M., García-Ortega, M., Valdez-Moreno, M., and Azueta, J.O. 2014. Artisanal recreational fisheries: using a combined approach to fishery assessment aimed at providing insights for fishery managers. Marine Resour. Econ. 29(2): 89-109. Available from http://www.bioone.org/doi/pdf/10.1086/676838 [accessed 22 October 2015].

Ratnasingham, S., and Hebert, P.D.N. 2007. BOLD: the barcode of life data system (www.barcodinglife.org). Mol. Ecol. Notes. 7: 355-364. Available from

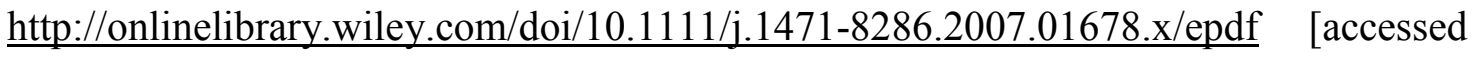
22 October 2015].

Ratnasingham S., and Hebert P.D.N. 2013. A DNA-Based Registry for All Animal Species: The Barcode Index Number (BIN) System. PLoS ONE. 8(7): e66213. Available

from 
http://journals.plos.org/plosone/article?id=10.1371/journal.pone.0066213 [accessed 22 October 2015].

Richards, W.J. 1985. Status of the identification of the early life stages of fishes. Bulletin of $\begin{array}{lllll}\text { Marine } & \text { Sci. } & \text { 37(2): } & \text { 756-760. } & \text { Available }\end{array}$ http://docserver.ingentaconnect.com/deliver/connect/umrsmas/00074977/v37n2/s36.pd $\underline{\text { f?expires }=1445499004 \& \mathrm{id}=83162386 \& \text { titleid }=10983 \& \text { accname }=\text { Guest }+ \text { User } \& \text { checks }}$ $\underline{\mathrm{um}=393 \mathrm{E} 64 \mathrm{~A} 764 \mathrm{FB} 082 \mathrm{CB} 15 \mathrm{BD} 102 \mathrm{BFC} 4 \mathrm{~B} 36 \mathrm{~B}}$ [accessed 22 October 2015].

Richards, W.J. 2006. Early Stages of Atlantic Fishes: An Identification Guide for the Western Central North Atlantic. CRC Press, Boca Ratón, FL.

Richardson, D.E., Vanwye, J.D., Exum, A.M., Cowen, R.K., and Crawford, D.L. 2007. High-throughput species identification: from DNA isolation to bioinformatics. Mol. $\begin{array}{lllll}\text { Ecol. } & \text { Notes. } & \text { 199-207. } & \text { Available }\end{array}$ http://onlinelibrary.wiley.com/doi/10.1111/j.1471-8286.2006.01620.x/pdf [accessed 22 October 2015].

Robins, C.R., and Ray, G.C. 1986. A field guide to Atlantic coast fishes of North America. Houghton Mifflin Company, Boston, MA.

Rock, J., Costa, F.O., Walker, D.I., North, A.W., Hutchinson, W.F., and Carvalho, G.R. 2008. DNA barcodes of fish of the Scotia Sea, Antarctica indicate priority groups for taxonomic and systematics focus. Antarct. Sci. 20(3): 258-262. Available from 
http://journals.cambridge.org/action/displayFulltext?type=1\&fid=1875160\&jid=ANS\& volumeId=20\&issue $I d=03 \&$ aid $=1875152 \&$ bodyId $=$ \&membershipNumber $=\&$ societyE $\underline{\text { TOCSession }}=[$ accessed 22 October 2015].

Saitoh, K., Uehara, S., and Tega, T. 2008. Genetic identification of fish eggs collected in Sendai Bay and off Johban, Japan. Ichthyol. Resour. 56: 200-203. Available from

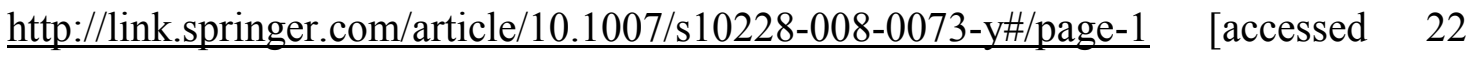
October 2015].

Saitou, N., and Nei, M. 1987. The neighbor-joining method: A new method for reconstructing phylogenetic trees. Mol. Biol. Evol. 4: 406-425. Available from $\underline{\text { http://mbe.oxfordjournals.org/content/4/4/406.full.pdf }+ \text { html }}$ [accessed 22 October 2015].

Schmitter-Soto, J.J., Vásquez-Yeomans, L., Aguilar-Pereira, A., Curiel-Mondragón, C., and Caballero-Vázquez, J.A. 2000. Lista de peces marinos del Caribe mexicano. Anales del Instituto de Biología Serie Zoología. 71: 143-177. Available from http://www.redalyc.org/pdf/458/45871204.pdf [accessed 22 October 2015].

Sosa-Cordero, E., Ramírez González, A., and Olivares Escobedo, J. 2009. Programa de Ordenamiento Pesquero del Estado de Quintana Roo. 1.- Pesquería de meros y especies afines. Informe Final presentado a CONAPESCA-SAGARPA. El Colegio de la Frontera Sur, Chetumal, Quintana Roo, Mexico. 
Valdez-Moreno, M.E., Vásquez-Yeomans, L., Elías-Gutiérrez, M., Ivanova, N.V., and Hebert, P.D.N. 2010. Using DNA barcodes to connect adults and early life stages of marine fishes from the Yucatan Peninsula, Mexico: potential in fisheries management. Marine Freshw. Res. 61: 665-671. Available from http://www.publish.csiro.au/index.cfm [accessed 22 October 2015].

Ward, R.D., Zemlak, T.S., Innes, B.H., Last, P.R., and Hebert, P.D.N. 2005. DNA barcoding Australia's fish species. Philos. Transact. Royal Soc. 360: 1847-1857. Available from http://www.ncbi.nlm.nih.gov/pmc/articles/PMC1609232/ [accessed 22 October 2015].

Ward, R.D., Costa, F.O., Holmes, B.H., and Steinke, D. 2008. DNA barcoding of shared fish species from the North Atlantic and Australasia: minimal divergence for most taxa, but Zeus faber and Lepidopus caudatus each probably constitute two species. Aquat. Biol. 3: 71-78. Available from http://www.intres.com/articles/ab2008/3/b003p071.pdf [accessed 22 October 2015]. 


\section{Figure captions}

Figure 1. Location of sample stations.

Figure 2. Neighbor-joining tree. The tree is based on genetic distances (K2P) of the COI gene. The height of each triangle represents the number of specimens sequenced, while the depth represents the genetic diversity present within each cluster.

Figure 3. Egg species richness by station. Circle size indicates number of taxa per station. The number of taxa was estimated was based in the identifications made in BOLD, including species bearing a Linnaean name and those currently recognized only by a BIN and higher-level identification.

Figure 4. Distribution of fish eggs from the most common species, A) Nesiarchus nasutus, B) Diplospinus multistriatus, and C) Regalecus glesne. 


\section{Table}

Table I. Morphological features of the studied eggs for 21 species.

* Species with eggs with different stage.

\begin{tabular}{|c|c|c|c|c|c|c|c|c|c|c|}
\hline Species & $\begin{array}{l}\text { Sample } \\
\text { size }\end{array}$ & Shape & $\begin{array}{l}\text { Diam } \\
(\mathrm{mm})\end{array}$ & Chorion & $\begin{array}{l}\text { Perivitelline } \\
\text { space }\end{array}$ & Yolk & Oil globule & Pigmentation & Embryo & Observations \\
\hline $\begin{array}{l}\text { Ariomma } \\
\text { melanum }\end{array}$ & 4 & Spherical & 1 & Smooth & Narrow & Homogeneous & Absent & None & None & $\begin{array}{l}\text { There is a circle in } \\
\text { the chorion. }\end{array}$ \\
\hline $\begin{array}{l}\text { Calamus } \\
\text { calamus }\end{array}$ & 8 & Spherical & 1 & $\begin{array}{l}\text { Smooth and } \\
\text { transparent }\end{array}$ & Narrow & Homogeneous & Absent & $\begin{array}{l}\text { Black spots in } \\
\text { the head of the } \\
\text { embryo. }\end{array}$ & $\begin{array}{l}\text { Large, with } \\
\text { a wide } \\
\text { head. }\end{array}$ & $\begin{array}{l}\text { Fertilized eggs, } \\
\text { with an } \\
\text { intussusception in } \\
\text { the yolk sac. }\end{array}$ \\
\hline Caranx hippos & 2 & Spherical & 0.5 & $\begin{array}{l}\text { Smooth and } \\
\text { transparent }\end{array}$ & Narrow & Homogeneous & Absent & None & None & Unfertilized egg \\
\hline $\begin{array}{l}\text { Chauliodus } \\
\text { danae }\end{array}$ & 2 & Spherical & 1.7 & $\begin{array}{l}\text { Smooth and } \\
\text { transparent }\end{array}$ & Undefined & Undefined & Absent & None & None & Unfertilized egg \\
\hline $\begin{array}{l}\text { Decapterus } \\
\text { punctatus }\end{array}$ & 7 & Spherical & 0.5 & $\begin{array}{l}\text { Smooth and } \\
\text { transparent }\end{array}$ & Narrow & Homogeneous & Absent & None & None & Unfertilized egg \\
\hline $\begin{array}{l}\text { Diplospinus } \\
\text { multistriatus }\end{array}$ & 54 & Spherical & $1-1.1$ & $\begin{array}{l}\text { Smooth and } \\
\text { transparent }\end{array}$ & Narrow & Homogeneous & Some & $\begin{array}{l}\text { Stains in the } \\
\text { head and some } \\
\text { around. } 1 \text { spot } \\
\text { more in the tail. }\end{array}$ & $\begin{array}{l}\text { Slim, in } \\
\text { some cases } \\
\text { with caudal } \\
\text { fin forming. }\end{array}$ & $\begin{array}{l}\text { Fertilized eggs, } \\
\text { with an } \\
\text { intussusception in } \\
\text { the yolk sac with } \\
\text { pigments inside. }\end{array}$ \\
\hline $\begin{array}{l}\text { Gempylus } \\
\text { serpens }\end{array}$ & 11 & Spherical & 0.8 & $\begin{array}{l}\text { Smooth and } \\
\text { transparent }\end{array}$ & Narrow & Homogeneous & Absent & None & None & Unfertilized eggs \\
\hline Kajikia albida* & 3 & Spherical & $0.6-1$ & $\begin{array}{l}\text { Smooth and } \\
\text { transparent }\end{array}$ & Narrow & Homogeneous & Some & $\begin{array}{l}\text { In the dorsal } \\
\text { part of the } \\
\text { embryo, and the } \\
\text { yolk sac. The } \\
\text { pigments are } \\
\text { tenuous. }\end{array}$ & $\begin{array}{l}\text { Short and } \\
\text { thin, head } \\
\text { just being } \\
\text { formed. } \\
\text { Still } \\
\text { without } \\
\text { eyes } \\
\text { formation. }\end{array}$ & $\begin{array}{l}\text { Fertilized eggs } \\
\text { with an } \\
\text { intussusception in } \\
\text { the yolk sac, with } \\
\text { pigments inside. }\end{array}$ \\
\hline
\end{tabular}




\begin{tabular}{|c|c|c|c|c|c|c|c|c|c|c|}
\hline \multirow{4}{*}{$\begin{array}{l}\text { Katsuwonus } \\
\text { pelamis* }\end{array}$} & 6 & Spherical & $\begin{array}{l}0.9- \\
1.1\end{array}$ & $\begin{array}{l}\text { Smooth and } \\
\text { transparent }\end{array}$ & Narrow & Homogeneous & Some & $\begin{array}{l}\text { Dark, asterisk- } \\
\text { shaped } \\
\text { pigments, focus } \\
\text { on the dorsal } \\
\text { part of the } \\
\text { embryo. }\end{array}$ & $\begin{array}{l}\text { Could not } \\
\text { appreciate } \\
\text { the head. } \\
\text { Thicker } \\
\text { body which } \\
\text { tapers } \\
\text { towards the } \\
\text { tail. }\end{array}$ & $\begin{array}{l}\text { With an } \\
\text { intussusception in } \\
\text { the yolk sac, with } \\
\text { pigments inside. }\end{array}$ \\
\hline & 2 & Spherical & $0.9-1$ & $\begin{array}{l}\text { Smooth and } \\
\text { tranparent }\end{array}$ & Medium & Homogeneus & Absent & None & None & No fertilized \\
\hline & 5 & Spherical & 0.9 & $\begin{array}{l}\text { Smooth and } \\
\text { transparent }\end{array}$ & Medium & Homogeneous & Absent & $\begin{array}{l}\text { Black and } \\
\text { circular } \\
\text { pigments in the } \\
\text { dorsal part of } \\
\text { the embryo. }\end{array}$ & $\begin{array}{l}\text { Could not } \\
\text { appreciate } \\
\text { the head } \\
\text { and tail } \\
\text { because all } \\
\text { body have } \\
\text { almost the } \\
\text { same } \\
\text { thickness. }\end{array}$ & $\begin{array}{l}\text { The eggs have an } \\
\text { intussusception in } \\
\text { the yolk sac with } \\
\text { black pigments } \\
\text { inside. }\end{array}$ \\
\hline & 124 & Spherical & 0.8 & $\begin{array}{l}\text { Smooth and } \\
\text { transparent }\end{array}$ & Medium & Homogeneous & Absent & $\begin{array}{l}\text { The pigments } \\
\text { bind forming } \\
\text { spots in the } \\
\text { dorsal part of } \\
\text { the embryo. }\end{array}$ & $\begin{array}{l}\text { Large, the } \\
\text { head and } \\
\text { tail almost } \\
\text { touch. Head } \\
\text { slightly } \\
\text { thicker than } \\
\text { the rest of } \\
\text { the body. }\end{array}$ & $\begin{array}{l}\text { The eggs have an } \\
\text { intussusception in } \\
\text { the yolk sac with } \\
\text { black pigments } \\
\text { inside. }\end{array}$ \\
\hline $\begin{array}{l}\text { Lactophrys } \\
\text { trigonus }\end{array}$ & 4 & Spherical & 1.3 & $\begin{array}{l}\text { Smooth and } \\
\text { transparent }\end{array}$ & Narrow & $\begin{array}{l}\text { Homogeneous } \\
\text { with black spots }\end{array}$ & Absent & $\begin{array}{l}\text { Pigments brown } \\
\text { color in the } \\
\text { embryo and the } \\
\text { yolk. }\end{array}$ & $\begin{array}{l}\text { Wide head } \\
\text { with eyes is } \\
\text { forming. }\end{array}$ & $\begin{array}{l}\text { Fertilized egg, } \\
\text { with an } \\
\text { intussusception in } \\
\text { the yolk sac. }\end{array}$ \\
\hline $\begin{array}{l}\text { Nesiarchus } \\
\text { nasutus }\end{array}$ & 451 & Spherical & $\begin{array}{l}0.5- \\
0.7\end{array}$ & $\begin{array}{l}\text { Transparent } \\
\text { and wrinkled }\end{array}$ & Narrow & Homogeneous & Absent & None & $\begin{array}{l}\text { Embryo } \\
\text { short and } \\
\text { with the } \\
\text { same } \\
\text { thickness } \\
\text { along of the }\end{array}$ & $\begin{array}{l}\text { Fertilized and } \\
\text { unfertilized eggs, } \\
\text { with an } \\
\text { intussusception in } \\
\text { the yolk sac. }\end{array}$ \\
\hline
\end{tabular}




\begin{tabular}{|c|c|c|c|c|c|c|c|c|c|c|}
\hline & & & & & & & & & body. & \\
\hline $\begin{array}{l}\text { Priacanthus } \\
\text { arenatus }\end{array}$ & 1 & Spherical & 0.6 & $\begin{array}{l}\text { Transparent } \\
\text { and wrinkled }\end{array}$ & Medium & Homogeneous & Absent & $\begin{array}{l}\text { Black spots in } \\
\text { the dorsal part } \\
\text { of the embryo. }\end{array}$ & $\begin{array}{l}\text { Newly } \\
\text { formed, is } \\
\text { not enough } \\
\text { to } \\
\text { distinguish } \\
\text { the head. }\end{array}$ & $\begin{array}{l}\text { Fertilized egg, } \\
\text { with an } \\
\text { intussusception in } \\
\text { the yolk sac with } \\
\text { pigments inside. } \\
\text { There is a circle in } \\
\text { the chorion with } \\
\text { black spots. }\end{array}$ \\
\hline $\begin{array}{l}\text { Prognichthys } \\
\text { occidentalis }\end{array}$ & 6 & Spherical & $1.8-2$ & $\begin{array}{l}\text { Transparent, } \\
\text { with short } \\
\text { cilia scattered }\end{array}$ & Narrow & Homogeneous & Absent & None & $\begin{array}{l}\text { Wide and a } \\
\text { big head } \\
\text { with eyes } \\
\text { forming. }\end{array}$ & $\begin{array}{l}\text { Fertilized and } \\
\text { unfertilized eggs. }\end{array}$ \\
\hline $\begin{array}{l}\text { Promethichthys } \\
\text { prometheus }\end{array}$ & 4 & Spherical & 0.8 & $\begin{array}{l}\text { Transparent } \\
\text { and wrinkled }\end{array}$ & Medium & Homogeneous & Absent & $\begin{array}{l}\text { Some in the } \\
\text { head of the } \\
\text { embryo. }\end{array}$ & $\begin{array}{l}\text { Slim, with } \\
\text { the head } \\
\text { forming. }\end{array}$ & $\begin{array}{l}\text { Fertilized eggs, } \\
\text { Apparently with a } \\
\text { double membrane. }\end{array}$ \\
\hline $\begin{array}{l}\text { Pterycombus } \\
\text { brama }\end{array}$ & 3 & Spherical & 1 & $\begin{array}{l}\text { Clear and } \\
\text { wrinkled }\end{array}$ & Narrow & Homogeneous & Some & None & $\begin{array}{l}\text { Slim, with } \\
\text { the head } \\
\text { forming. }\end{array}$ & Fertilized eggs \\
\hline \multirow[t]{3}{*}{$\begin{array}{l}\text { Remora } \\
\text { osteochir* }\end{array}$} & 2 & Spherical & $\begin{array}{l}1.2- \\
1.3\end{array}$ & $\begin{array}{l}\text { Smooth and } \\
\text { clear }\end{array}$ & Narrow & Homogeneous & Some & $\begin{array}{l}\text { Faint brown } \\
\text { points mainly in } \\
\text { the dorsal part } \\
\text { of the embryo. }\end{array}$ & $\begin{array}{l}\text { Thin, just } \\
\text { being } \\
\text { forming. }\end{array}$ & $\begin{array}{l}\text { Invagination not } \\
\text { yet seen in the } \\
\text { yolk sac. }\end{array}$ \\
\hline & 2 & 更 & 1.2 & $\begin{array}{l}\text { Smooth and } \\
\text { clear }\end{array}$ & Narrow & Homogeneous & Some & $\begin{array}{l}\text { Faint black } \\
\text { points mainly in } \\
\text { the dorsal part } \\
\text { of the embryo } \\
\text { and some in the } \\
\text { yolk sac. }\end{array}$ & $\begin{array}{l}\text { Thin, the } \\
\text { head and } \\
\text { eyes begin } \\
\text { to show. }\end{array}$ & $\begin{array}{l}\text { There is an } \\
\text { intussusception in } \\
\text { the yolk sac with } \\
\text { faint black points } \\
\text { around. }\end{array}$ \\
\hline & 2 & Spherical & $1-1.2$ & $\begin{array}{l}\text { Smooth and } \\
\text { clear }\end{array}$ & Narrow & Homogeneous & Some & $\begin{array}{l}\text { Points black in } \\
\text { the dorsal part } \\
\text { of the embryo } \\
\text { and around in } \\
\text { the yolk sac. }\end{array}$ & $\begin{array}{l}\text { Large, the } \\
\text { big head } \\
\text { and tail } \\
\text { meet. The } \\
\text { head and } \\
\text { eyes are }\end{array}$ & $\begin{array}{l}\text { There is an } \\
\text { intussusception in } \\
\text { the yolk sac, with } \\
\text { black points } \\
\text { inside. }\end{array}$ \\
\hline
\end{tabular}




\begin{tabular}{|c|c|c|c|c|c|c|c|c|c|c|}
\hline & & & & & & & & & formed. & \\
\hline Saurida normani & 1 & Spherical & 1.2 & $\begin{array}{l}\text { Smooth and } \\
\text { whitish }\end{array}$ & Narrow & Homogeneous & Absent & None & $\begin{array}{l}\text { Thin, just } \\
\text { forming }\end{array}$ & Fertilized egg \\
\hline $\begin{array}{l}\text { Scombrolabrax } \\
\text { heterolepis }\end{array}$ & 1 & Spherical & 0.8 & $\begin{array}{l}\text { Clear and } \\
\text { wrinkled }\end{array}$ & Narrow & Homogeneous & Absent & None & None & Unfertilized egg \\
\hline Synagrops bellus & 1 & Spherical & 0.7 & $\begin{array}{l}\text { Smooth and } \\
\text { transparent }\end{array}$ & Narrow & Homogeneous & Absent & None & None & Unfertilized egg \\
\hline Synodus synodus & 34 & Spherical & $\begin{array}{l}0.8- \\
0.9\end{array}$ & $\begin{array}{l}\text { Ornate with } \\
\text { hexagon } \\
\text { shaped } \\
\text { figures }\end{array}$ & Narrow & Homogeneous & Absent & None & $\begin{array}{l}\text { Frontal part } \\
\text { (head and } \\
\text { neck) } \\
\text { thickness } \\
\text { and the rest } \\
\text { of embryo } \\
\text { thin. }\end{array}$ & $\begin{array}{l}\text { Fertilized eggs, } \\
\text { Embryo similar to } \\
\text { S. intermedius. }\end{array}$ \\
\hline $\begin{array}{l}\text { Thunnus } \\
\text { atlanticus }\end{array}$ & 14 & Spherical & $\begin{array}{l}0.7- \\
1.5\end{array}$ & $\begin{array}{l}\text { Smooth and } \\
\text { unclear }\end{array}$ & Narrow & Homogeneous & Some & None & $\begin{array}{l}\text { Embryo is } \\
\text { just } \\
\text { forming. }\end{array}$ & $\begin{array}{l}\text { Mostly } \\
\text { unfertilized eggs, } \\
\text { only } 1 \text { fertilized } \\
\text { egg. }\end{array}$ \\
\hline $\begin{array}{l}\text { Trachinotus } \\
\text { falcatus }\end{array}$ & 1 & Spherical & 1 & $\begin{array}{l}\text { Smooth and } \\
\text { unclear }\end{array}$ & Narrow & Homogeneous & Absent & $\begin{array}{l}\text { Faint pigments } \\
\text { brown color in } \\
\text { the dorsal part } \\
\text { of the embryo. }\end{array}$ & $\begin{array}{l}\text { Eyes and } \\
\text { head } \\
\text { forming, } \\
\text { body and } \\
\text { head with } \\
\text { the same } \\
\text { thickness. }\end{array}$ & $\begin{array}{l}\text { Fertilized egg, } \\
\text { with an } \\
\text { intussusception in } \\
\text { the yolk sac, with } \\
\text { brown, faint spots } \\
\text { inside. }\end{array}$ \\
\hline
\end{tabular}




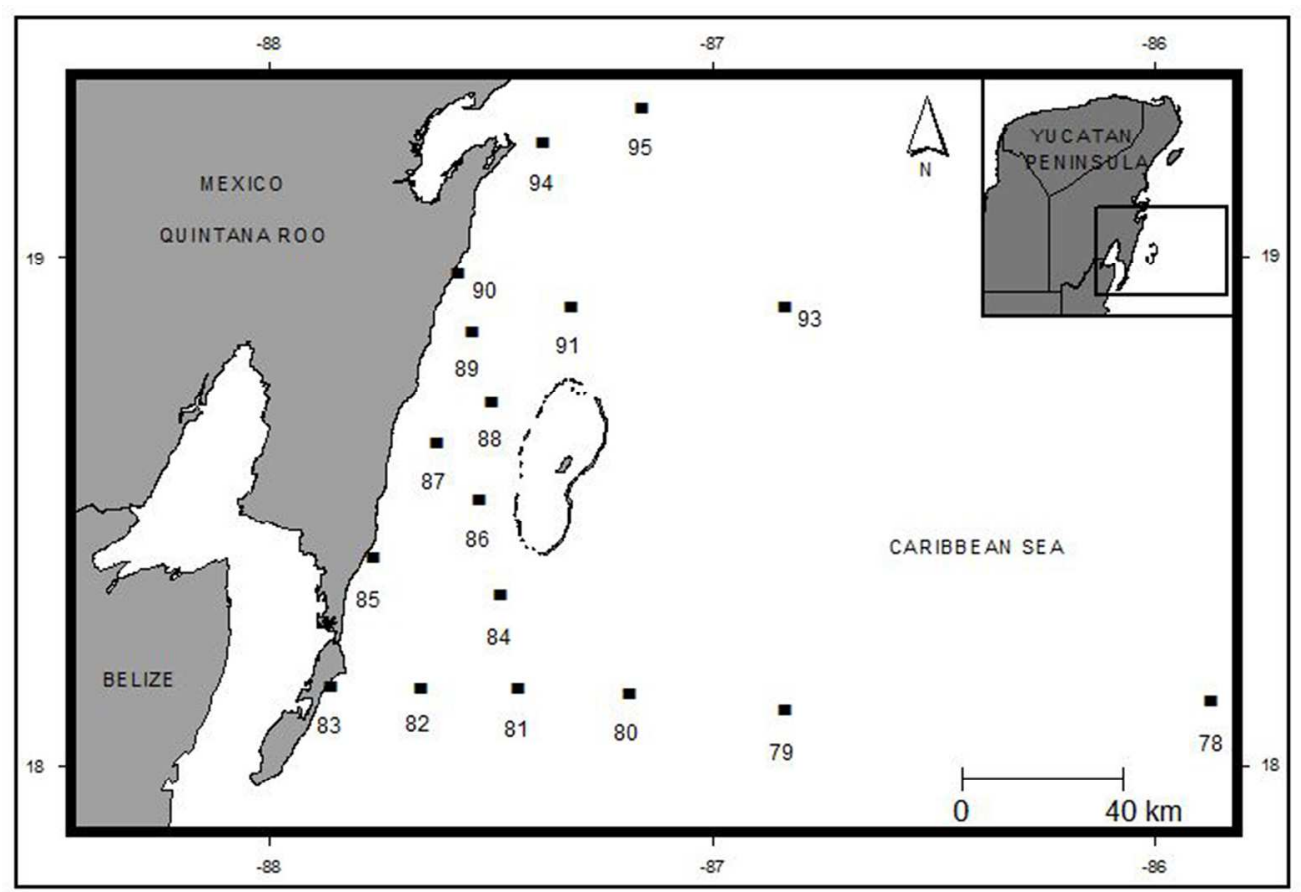

Figure 1. Location of sample stations. $180 \times 124 \mathrm{~mm}(300 \times 300 \mathrm{DPI})$ 

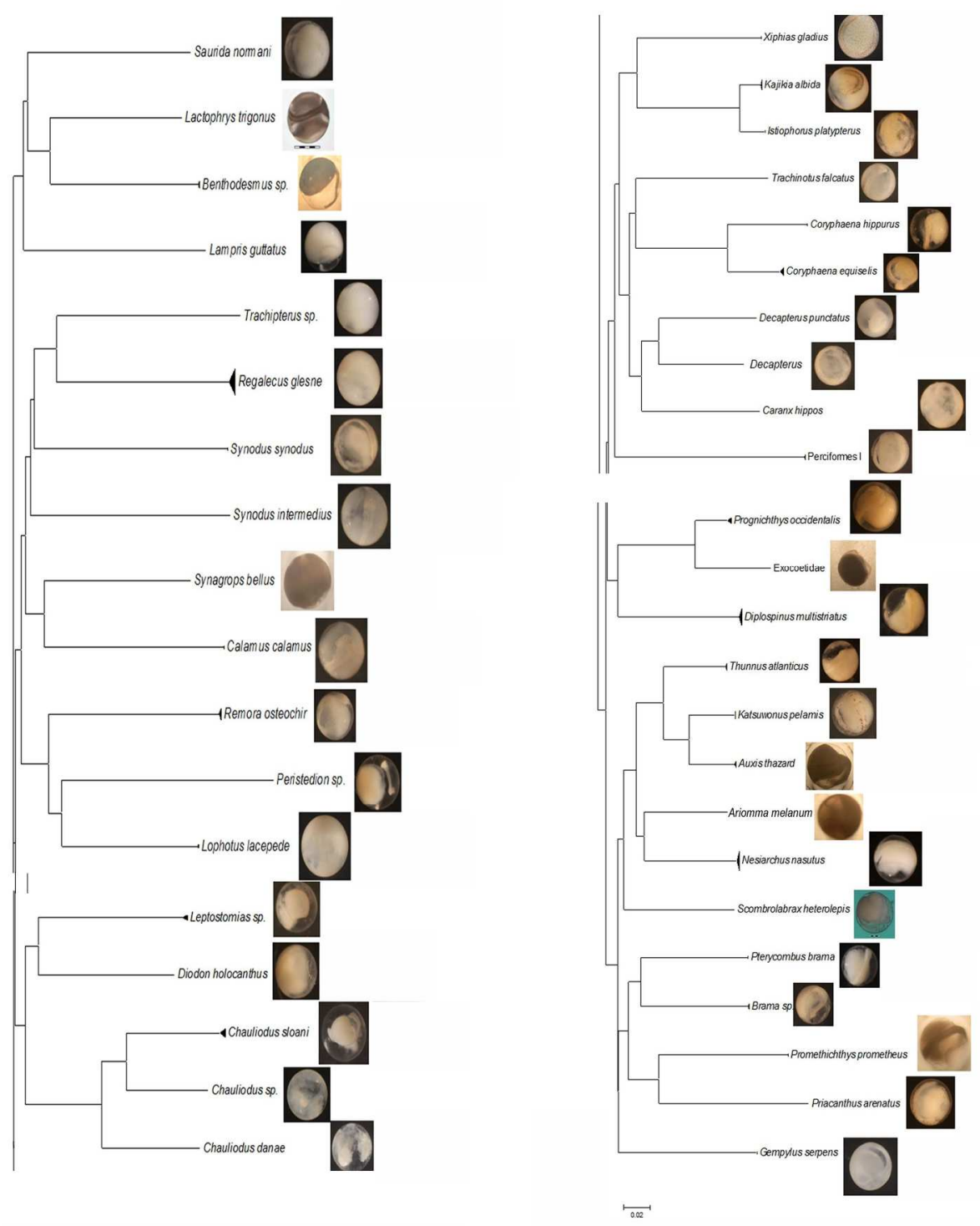

Figure 2. Neighbor-joining tree. The tree is based on genetic distances (K2P) of the COI gene. The height of each triangle represents the number of specimens sequenced while the depth represents the genetic diversity present within each cluster.

$226 \times 283 \mathrm{~mm}(300 \times 300$ DPI) 


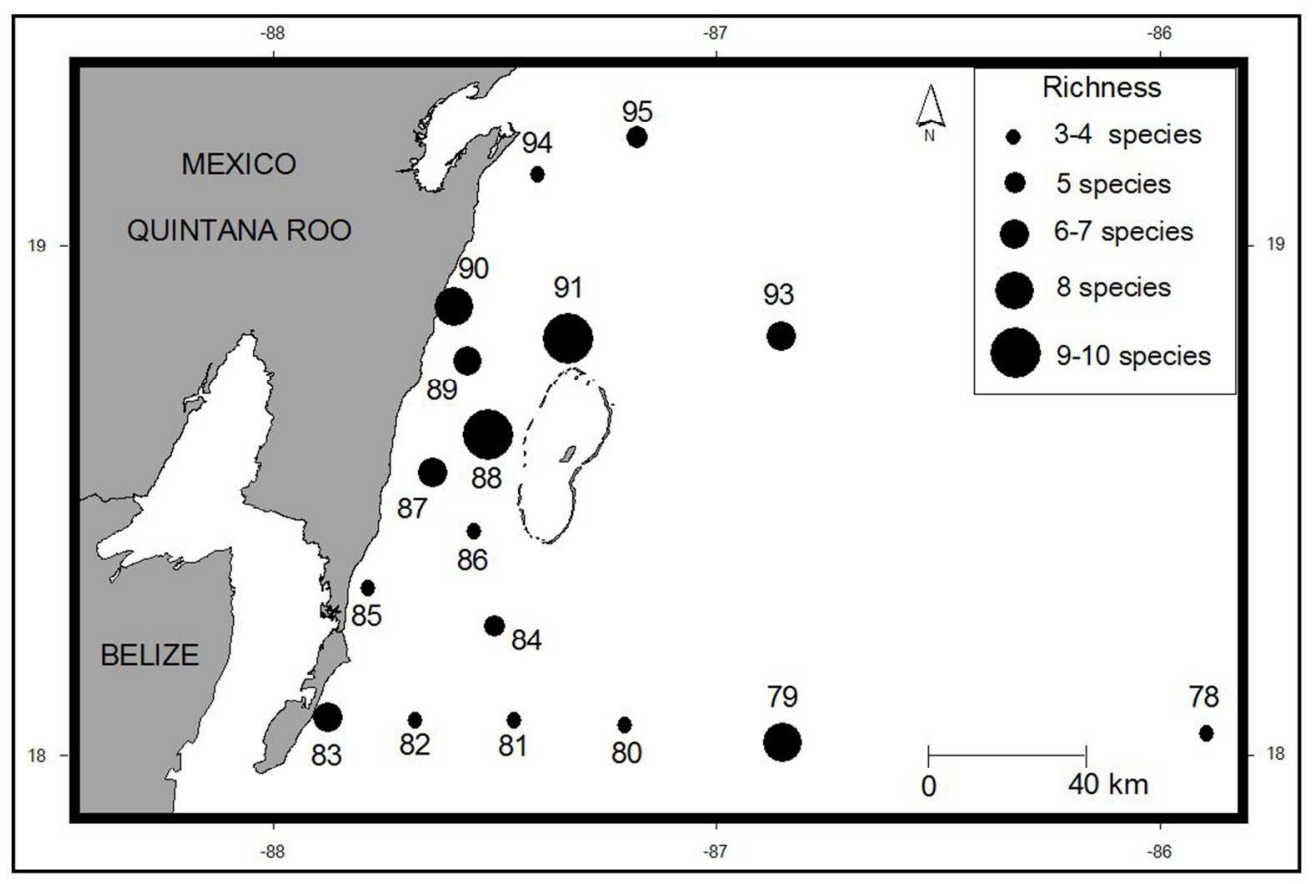

Figure 3. Egg species richness by station. Circle size indicates number of taxa per station. The number of taxa was estimated was based in the identifications made in BOLD, including all, not only the species with Linnean name.

$180 \times 124 \mathrm{~mm}(300 \times 300 \mathrm{DPI})$ 

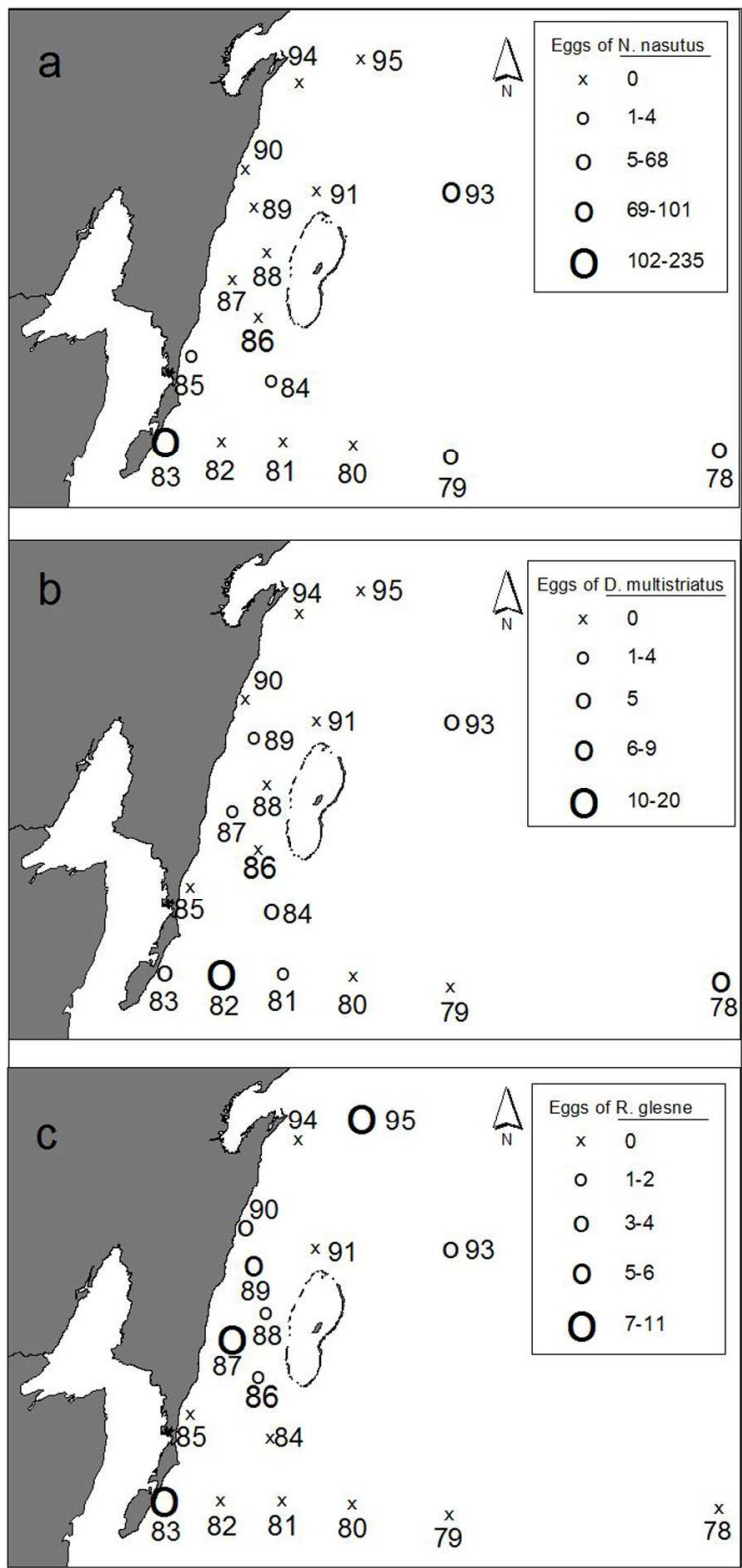

Figure 4. Distribution of fish eggs from the most common species, A) Nesiarchus nasutus, B) Diplospinus multistriatus, and C) Regalecus glesne. $180 \times 381 \mathrm{~mm}(300 \times 300 \mathrm{DPI})$ 
Lophotus lacepede|MXFEC097|BOLD:AAE1237

Lophotus lacepede|MXFEC261|BOLD:AAE1237

Regalecus glesne|MXFEC116|BOLD:AAF834

Regalecus glesne|MXFEC042|BOLD:AAF8341

Regalecus glesne|MXFEC083|BOLD:AAF8341

Regalecus glesne|MXFEC204|BOLD:AAF8341

-Regalecus glesne|MXFEC069|BOLD:AAF8341

-Regalecus glesne|MXFEC177|BOLD:AAF8341

Regalecus glesne|MXFEC038|BOLD:AAF8341

Regalecus glesne|MXFEC099|BOLD:AAF8341

Regalecus glesne|MXFEC226|BOLD:AAF8341

Regalecus glesne|MXFEC236|BOLD:AAF8341

Regalecus glesne|MXFEC263|BOLD:AAF8341

Regalecus glesne|MXFEC225|BOLD:AAF8341

Regalecus glesne|MXFEC075|

Regalecus glesne|MXFEC276|BOLD:AAF8341

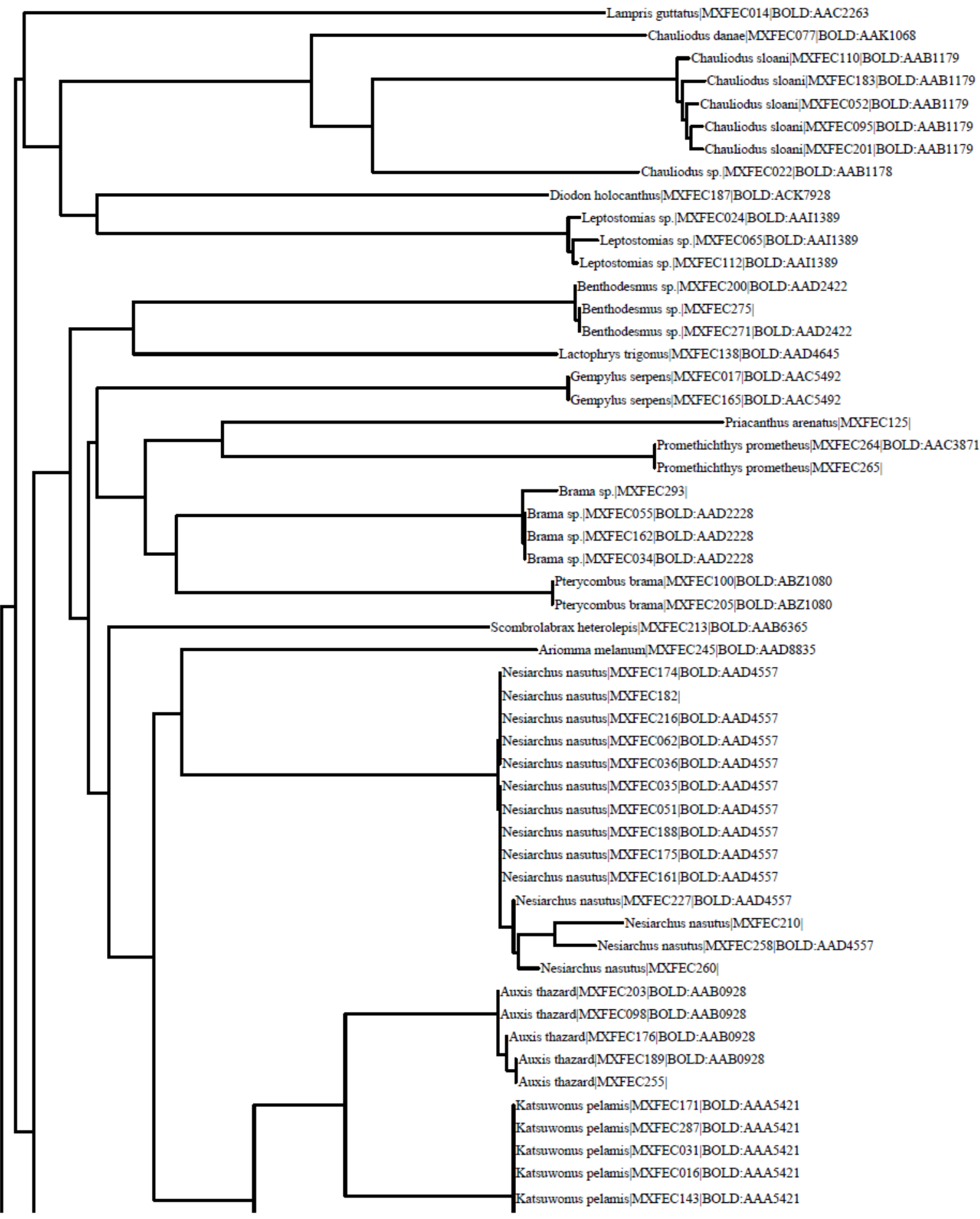

https://mc06.manuscriptcentral.com/genome-pubs 


\section{Genome}

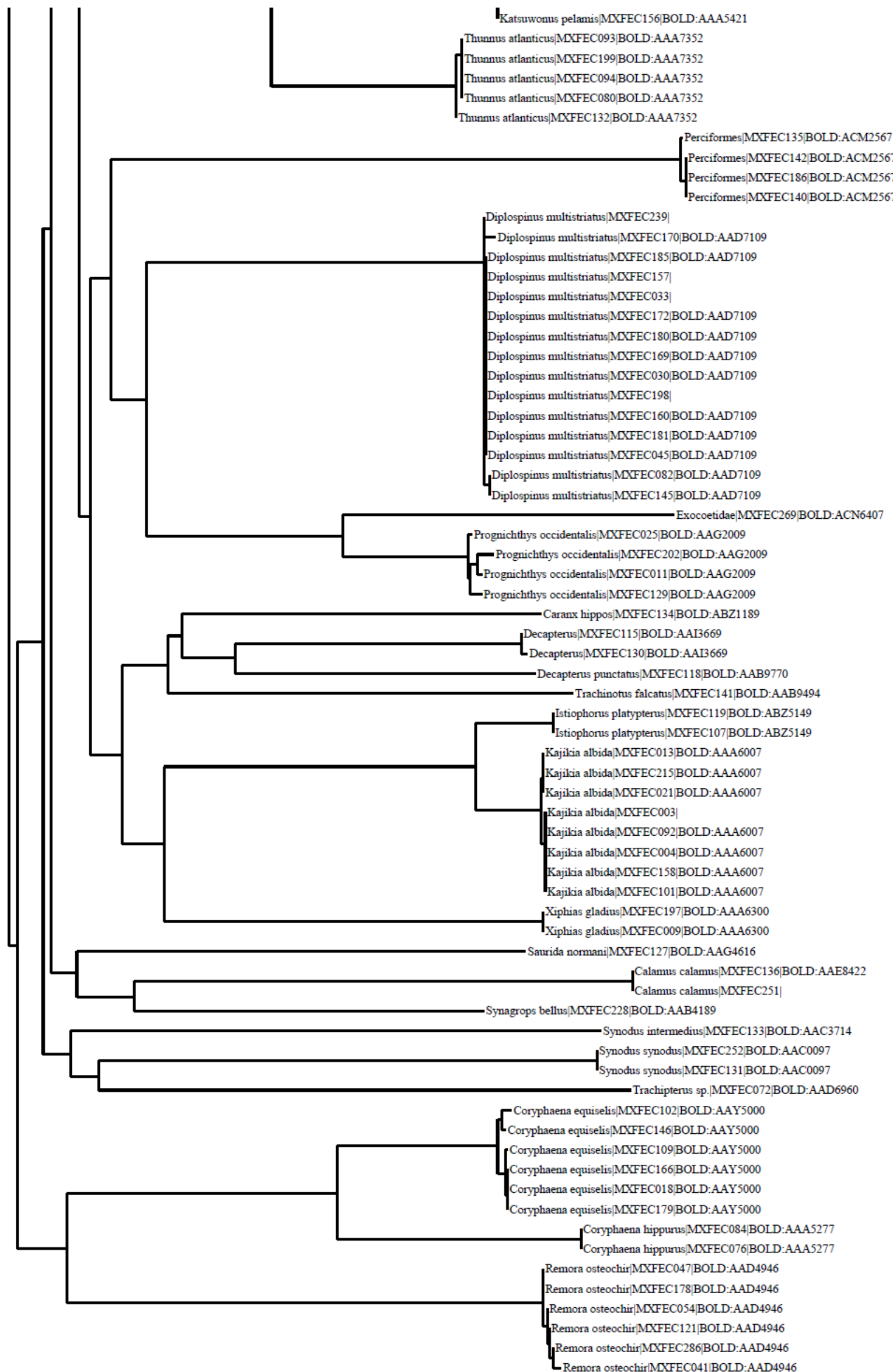

Figure S1. Neighbour-joining tree (K2P distance) of $139 \mathrm{CO}$ sequences from 42 marine fish eggs species. 

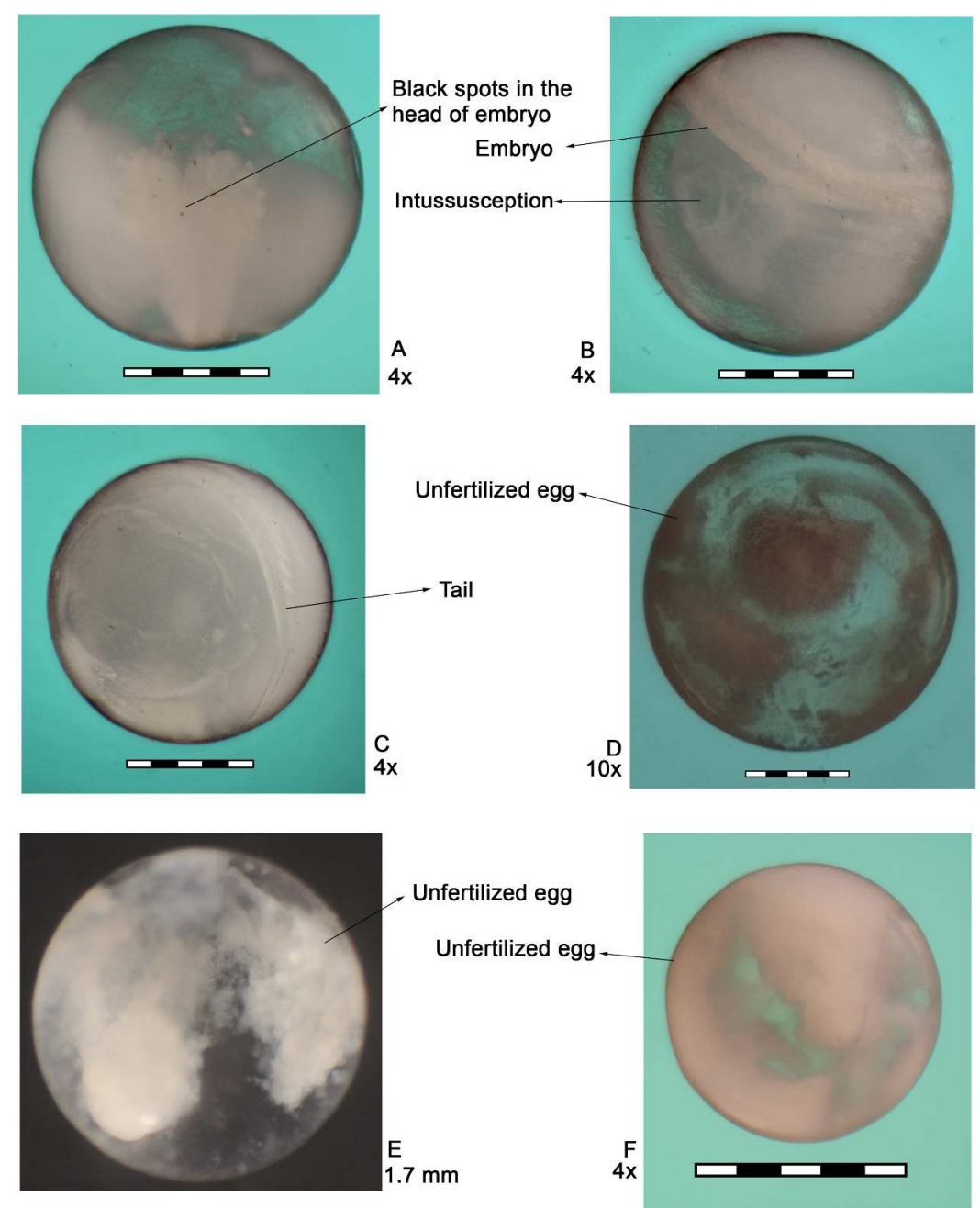

Figure S2. Calamus calamus (A, B, C) Caranx hippos (D), Chauliodus danae (E), Decapterus punctatus $(F)$. In the pictures with increase in $4 \mathrm{x}$, measuring slide equals $0.95 \mathrm{~mm}$ and with increase of $10 x$ equals $0.37 \mathrm{~mm}$. 

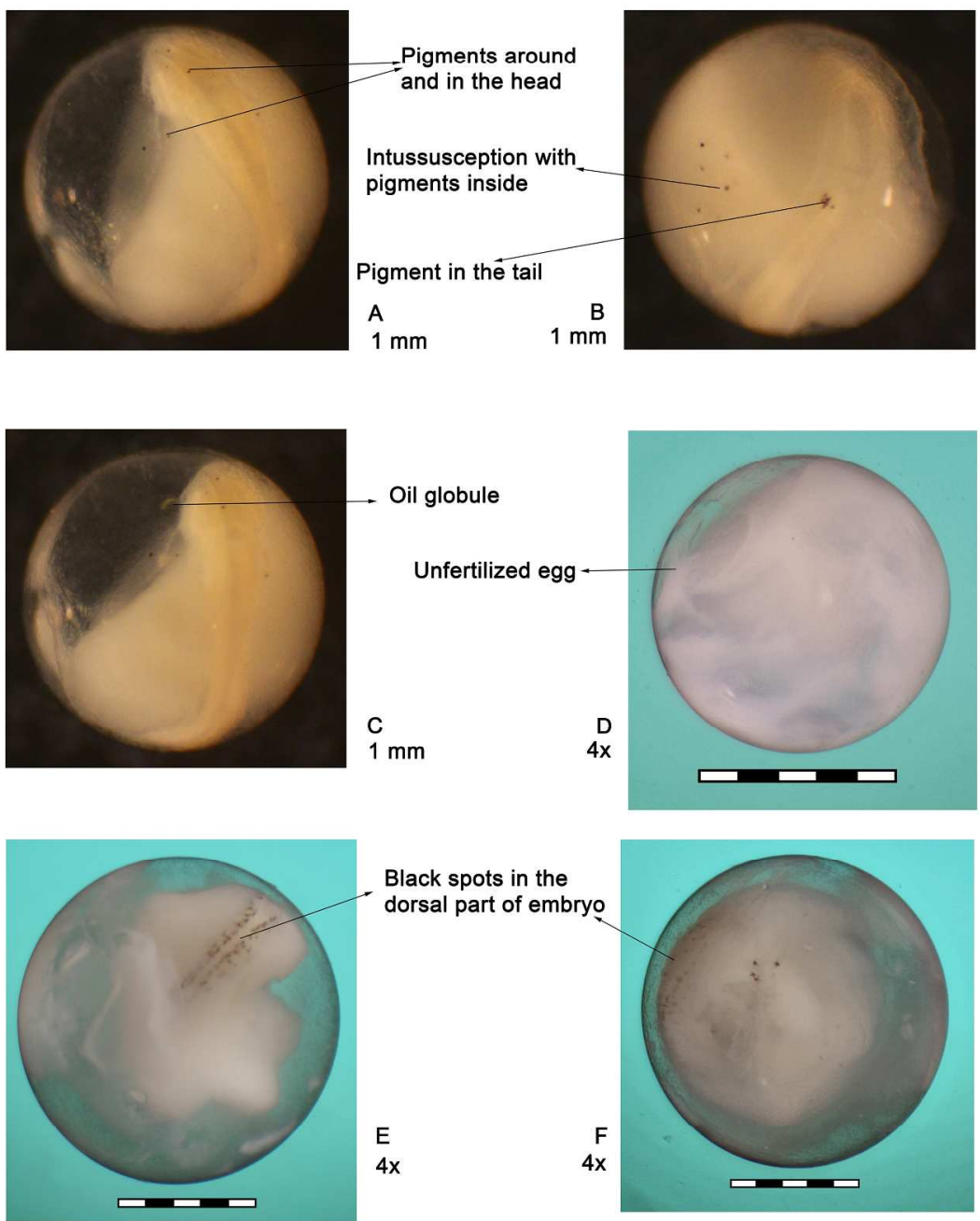

Figure S3. Diplospinus multistriatus (A, B, C), Gempylus serpens (D), Kajikia albida (E, F). In figures with increase $4 x$, the measuring slide equals $0.95 \mathrm{~mm}$.

$215 \times 279 \mathrm{~mm}(300 \times 300 \mathrm{DPI})$ 

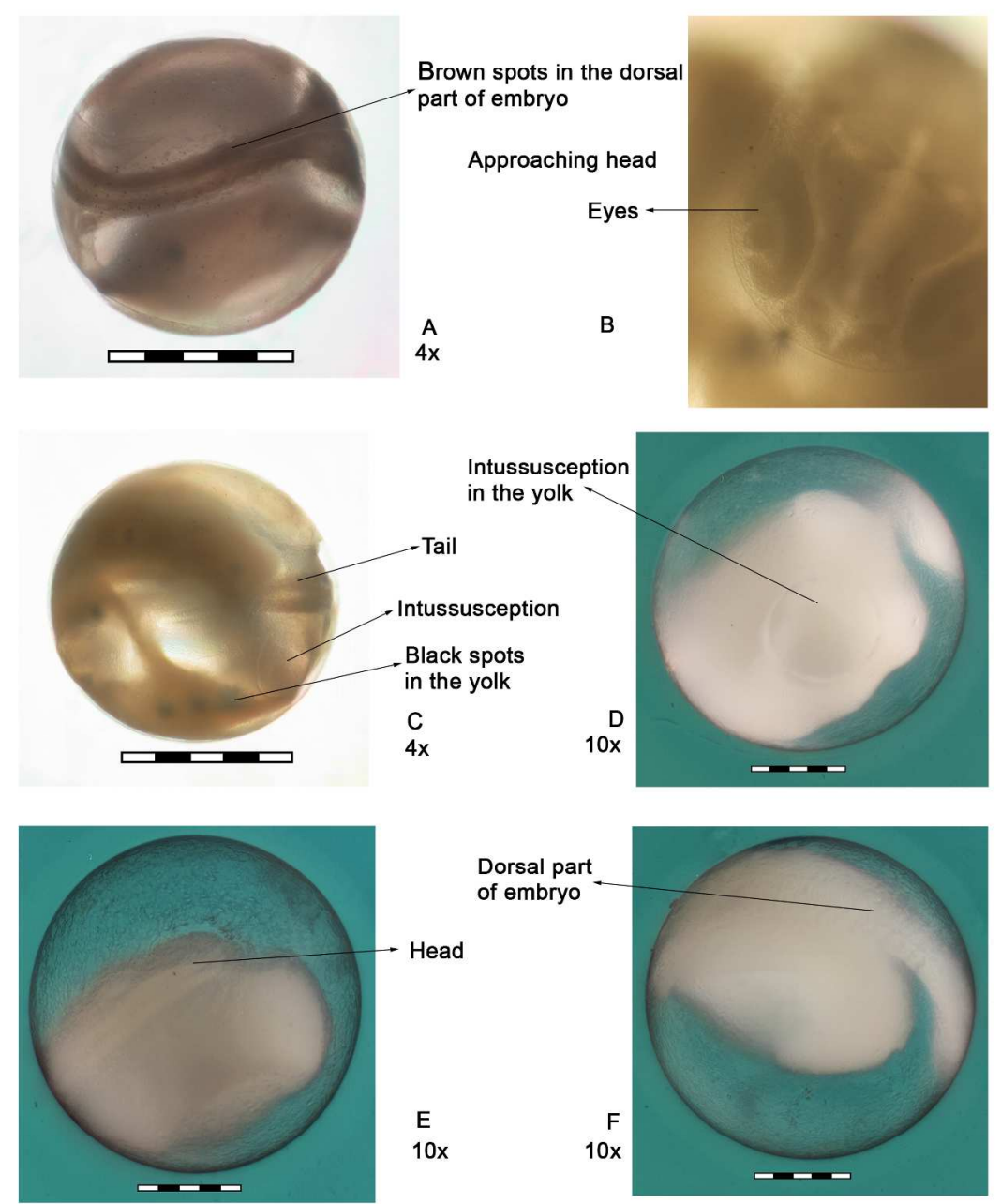

Figure S4. Lactophrys trigonus (A, B, C), Nesiarchus nasutus (D, E, F). In figures with increase of $4 x$, the measuring slide equals $0.95 \mathrm{~mm}$ and with an increase of 10x equals 0.37 $\mathrm{mm}$.

$215 \times 279 \mathrm{~mm}(300 \times 300 \mathrm{DPI})$ 

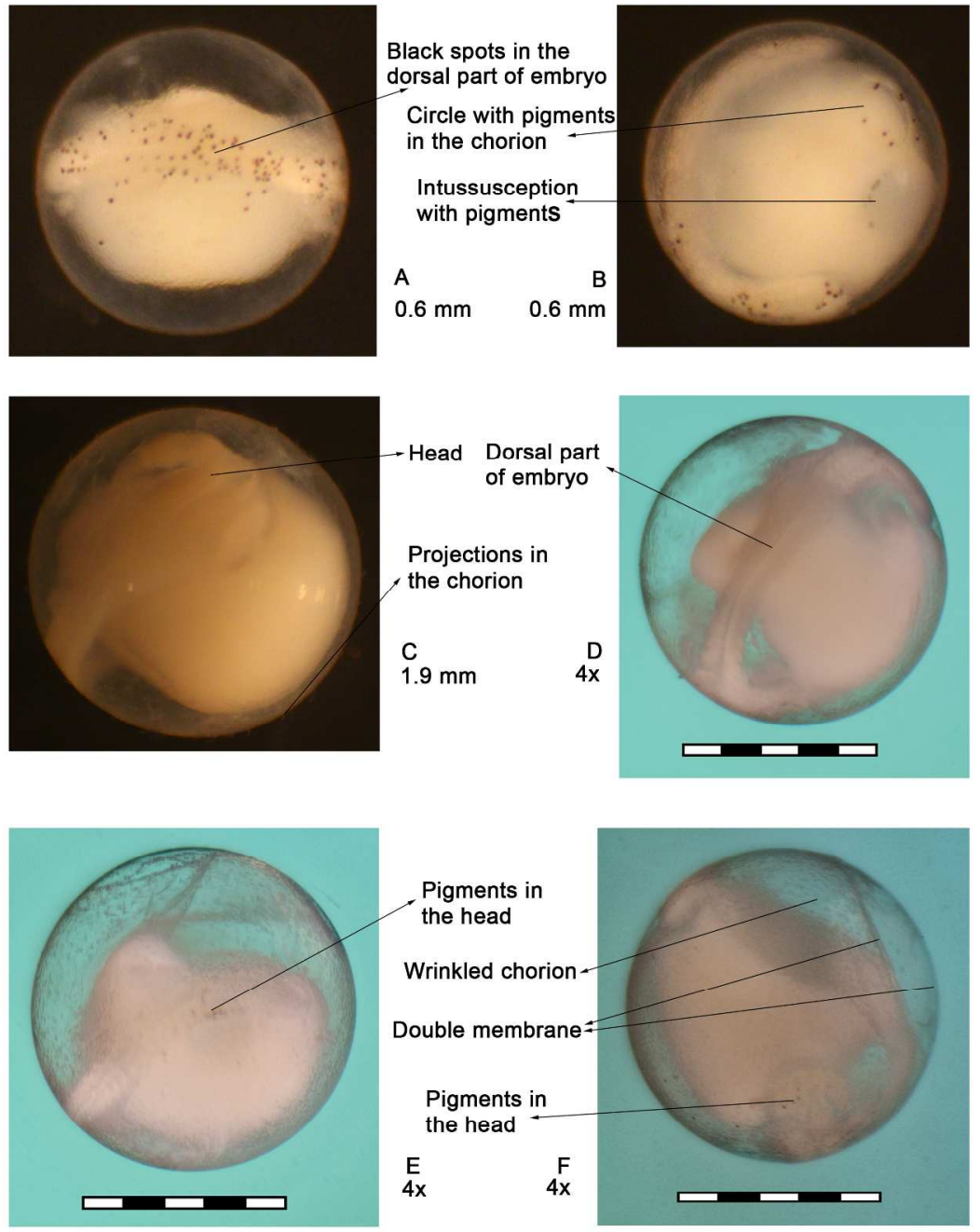

\section{Pigments in the head \\ Wrinkled chorion- \\ Double membrane \\ Pigments in the head $\underset{4 x}{F}$}

$E$
$4 x$

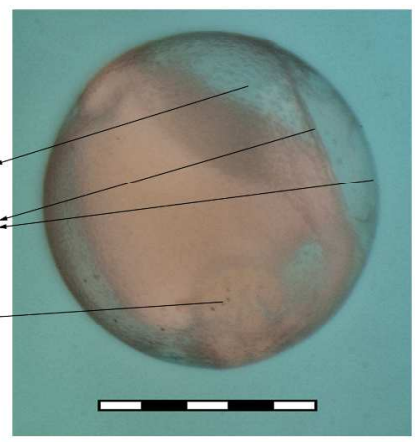

Figure S5. Priacanthus arenatus (A, B), Prognichthys occidentalis (C) Promethichthys prometheus $(D, E, F)$. In figures with increase $4 \mathrm{x}$, the measuring slide equals $0.95 \mathrm{~mm}$. 

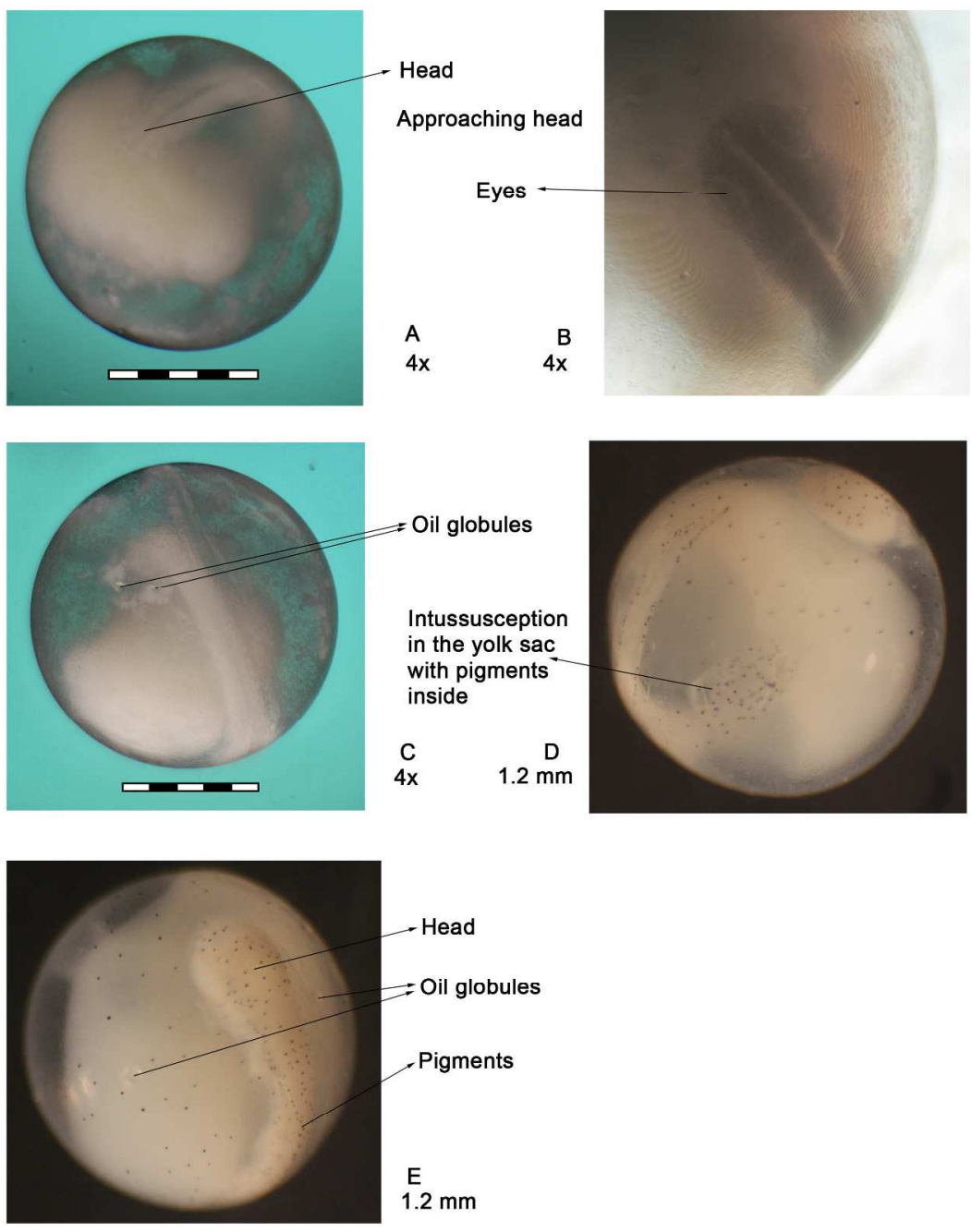

Figure S6. Pterycombus brama (A, B, C) and Remora osteochir (D, E). In images with increase $4 x$, the measuring slide equals $0.95 \mathrm{~mm}$.

$215 \times 279 \mathrm{~mm}(300 \times 300 \mathrm{DPI})$ 

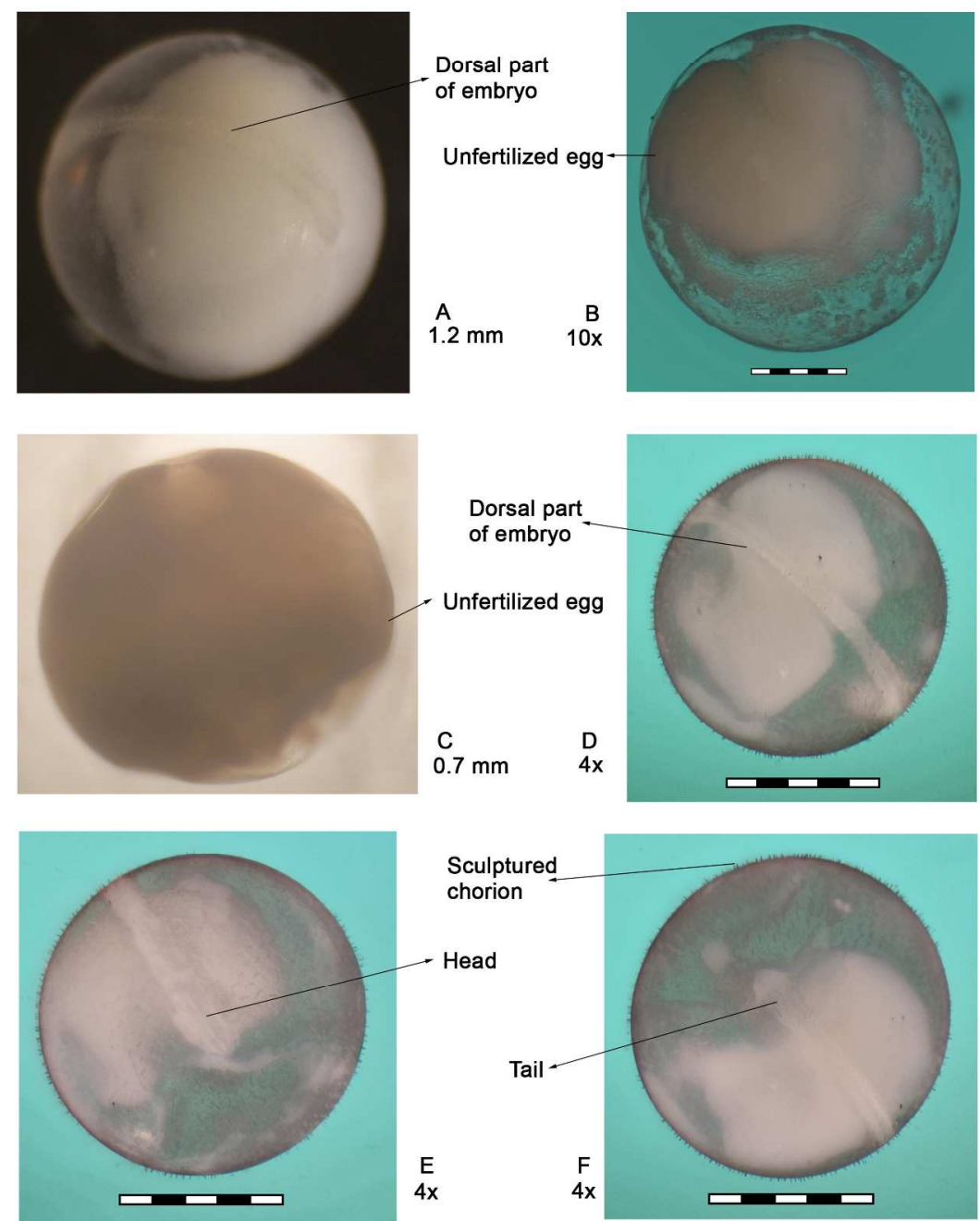

Figure S7. Saurida normani (A), Scombrolabrax heterolepis (B), Synagrops bellus (C) and Synodus synodus (D, E, F). In images with increase $4 \mathrm{x}$, the measuring slide equals 0.95 $\mathrm{mm}$ and an increase of $10 \mathrm{x}$ equals $0.37 \mathrm{~mm}$.

$215 \times 279 \mathrm{~mm}(300 \times 300 \mathrm{DPI})$ 

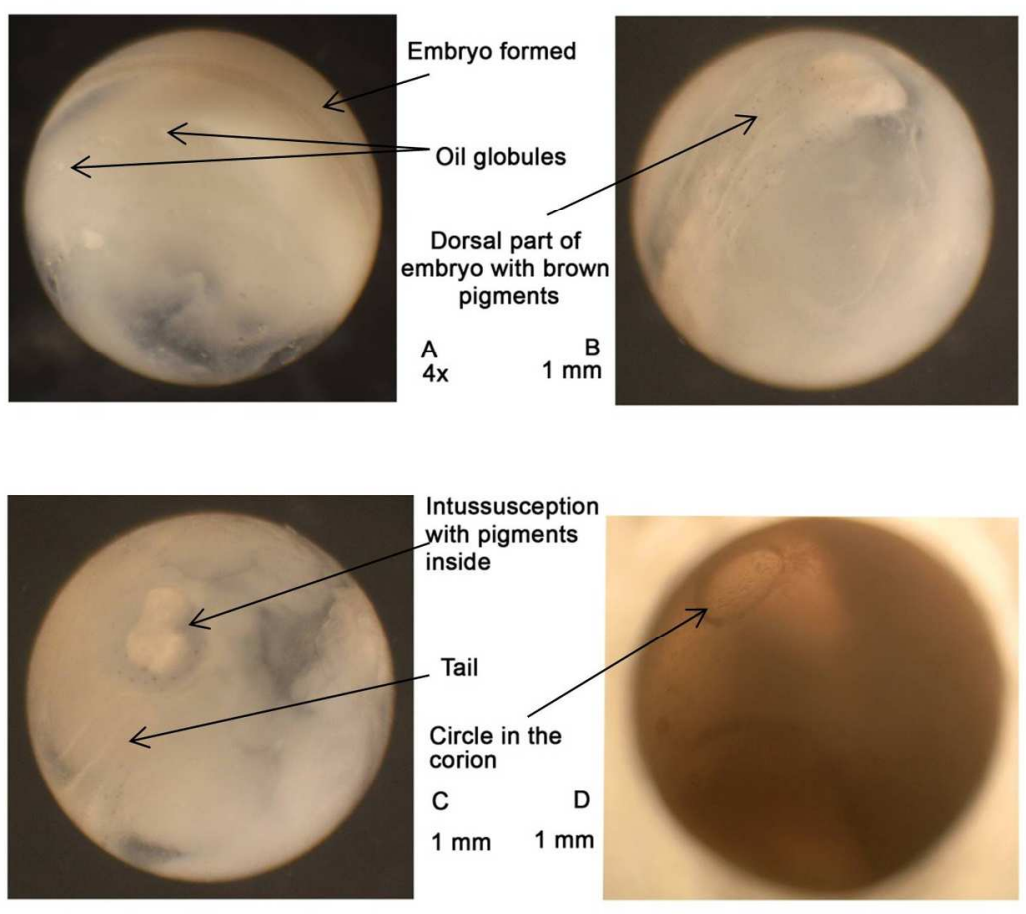

Figure S8. Thunnus atlanticus (A), Trachinotus falcatus (B, C) Ariomma melanum (D). In figures with increase $4 \mathrm{x}$ the measuring slide equals $0.95 \mathrm{~mm}$.

$147 \times 190 \mathrm{~mm}(300 \times 300$ DPI) 

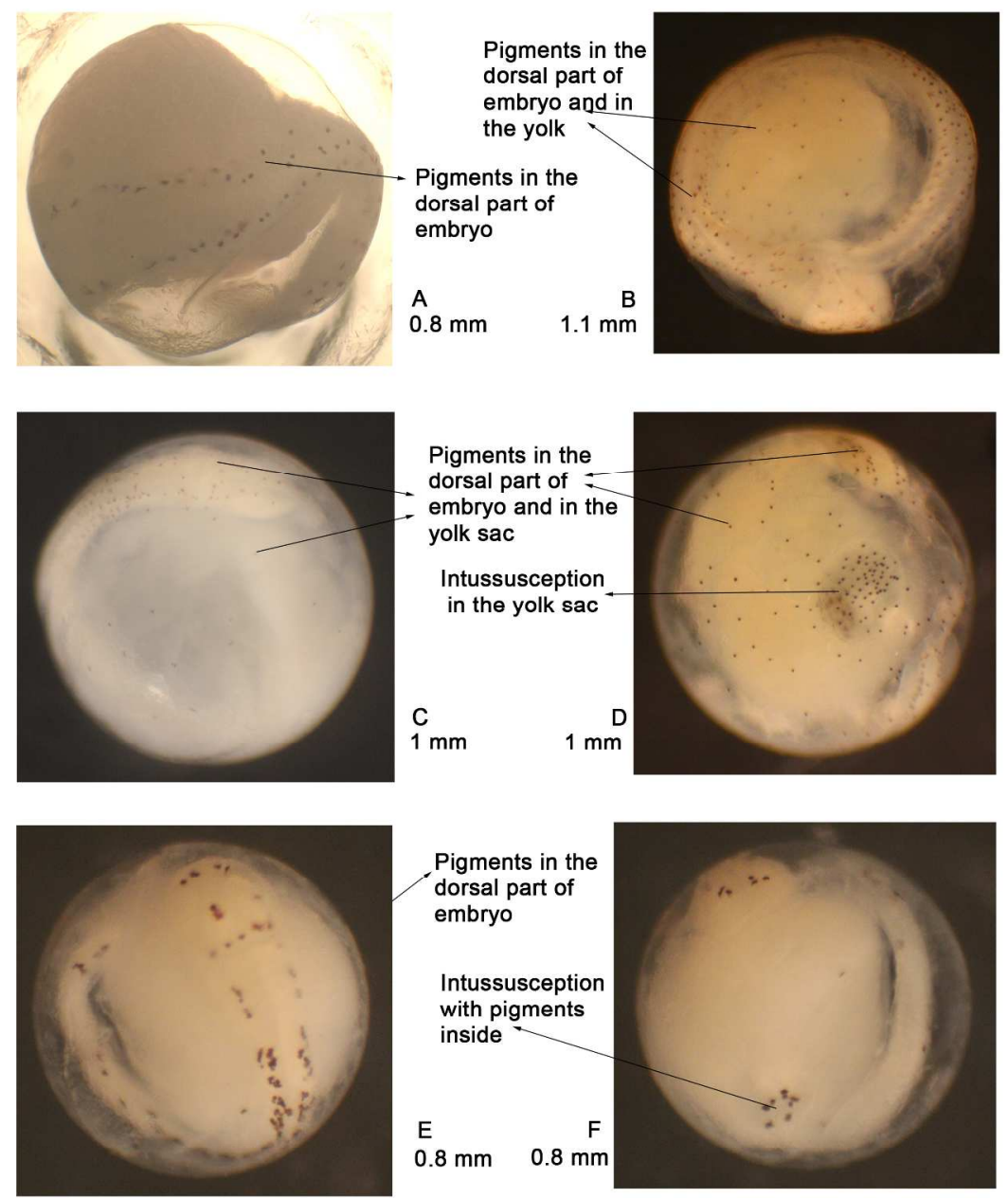

Figure S9. Auxis thazard (A), Coryphaena equiselis (B), Coryphaena hippurus (C),

Istiophorus platypterus (D) and Katsuwonus pelamis (E, F) without oil globules and the two latter species with an intussusception in the yolk sac. 

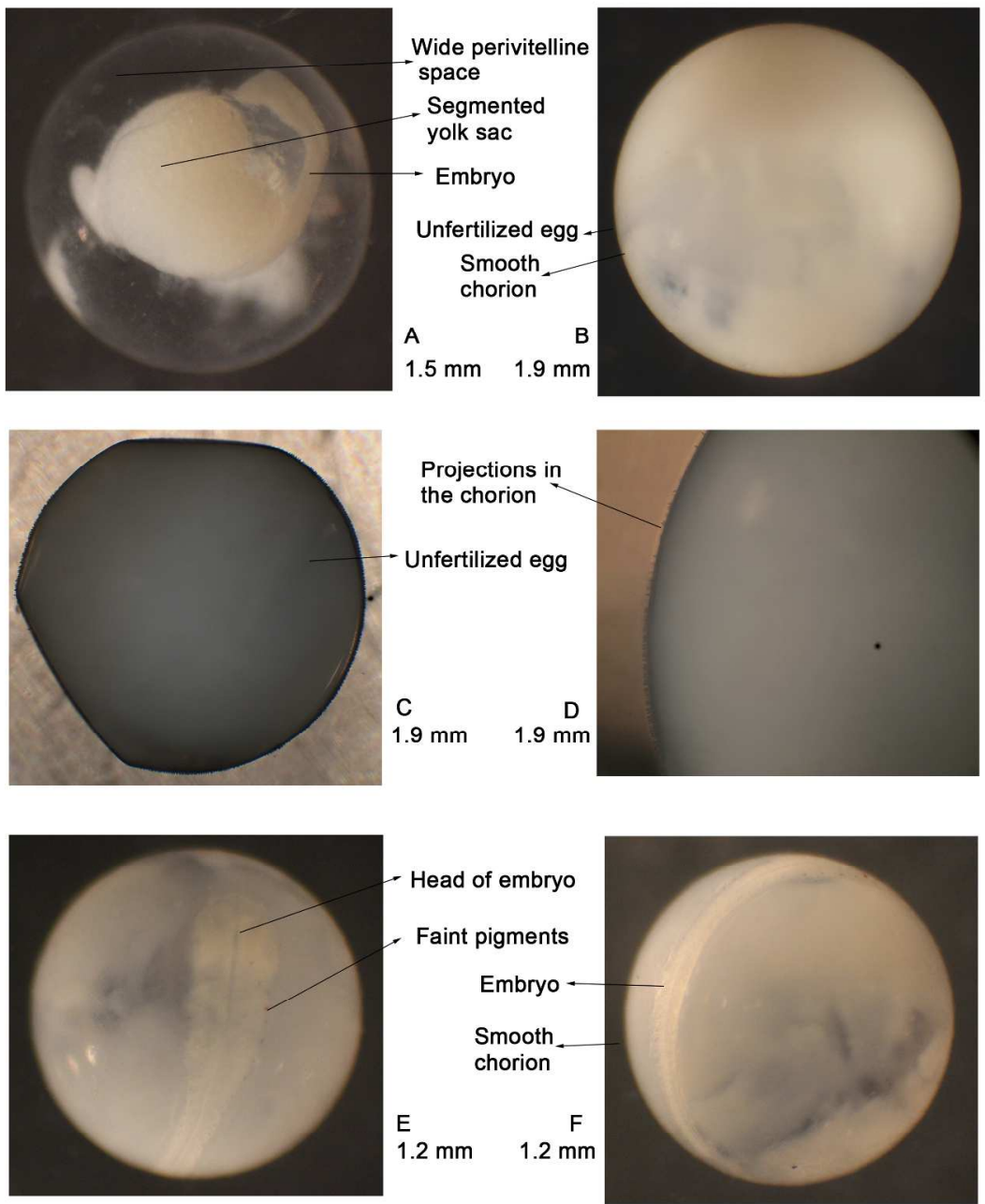

Figure S10. Chauliodus sloani (A) with wide perivitelline space and without double membrane. Lophotus lacepede (B) without spines, Regalecus glesne (C, D) with small projections and without oil globules and pigments. Synodus intermedius (E, F) with pigments in the head and without ornate corion.

$215 \times 279 \mathrm{~mm}(300 \times 300 \mathrm{DPI})$ 

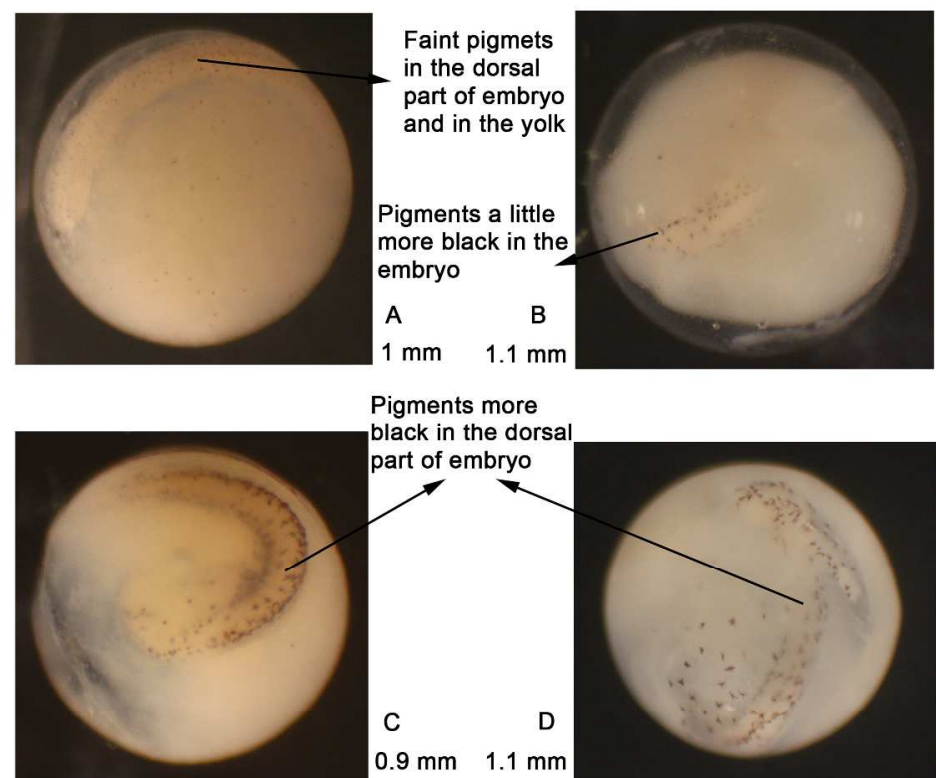

Figure S11. The images are from species Kajikia albida, pictures show the embryo with different level of development. Egg in picture A was found in station 78, B and $C$ in station 88 and $D$ in station 79.

$215 \times 279 m m(300 \times 300$ DPI) 


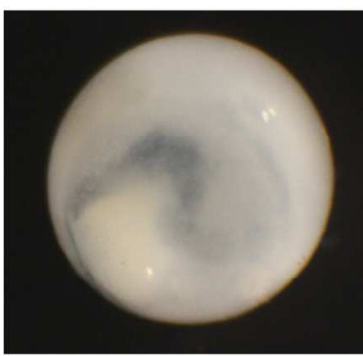

Unfertilized eggs
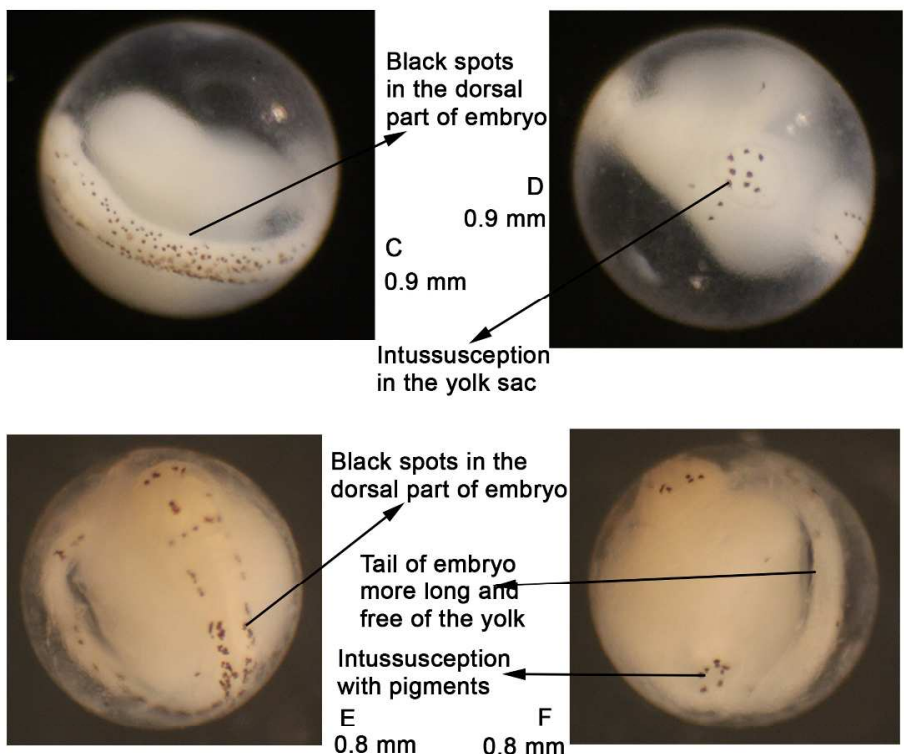

Figure S12. The figures are eggs from species Katsuwonus pelamis, each image shows the embryo with different level of development. Egg in the figure A was found in station 79 , egg in the figure $B$ in station $95, C$ and $D$ in station 82 , and $E$ and $F$ in station 93

\author{
$215 \times 279 \mathrm{~mm}(300 \times 300 \mathrm{DPI})$
}



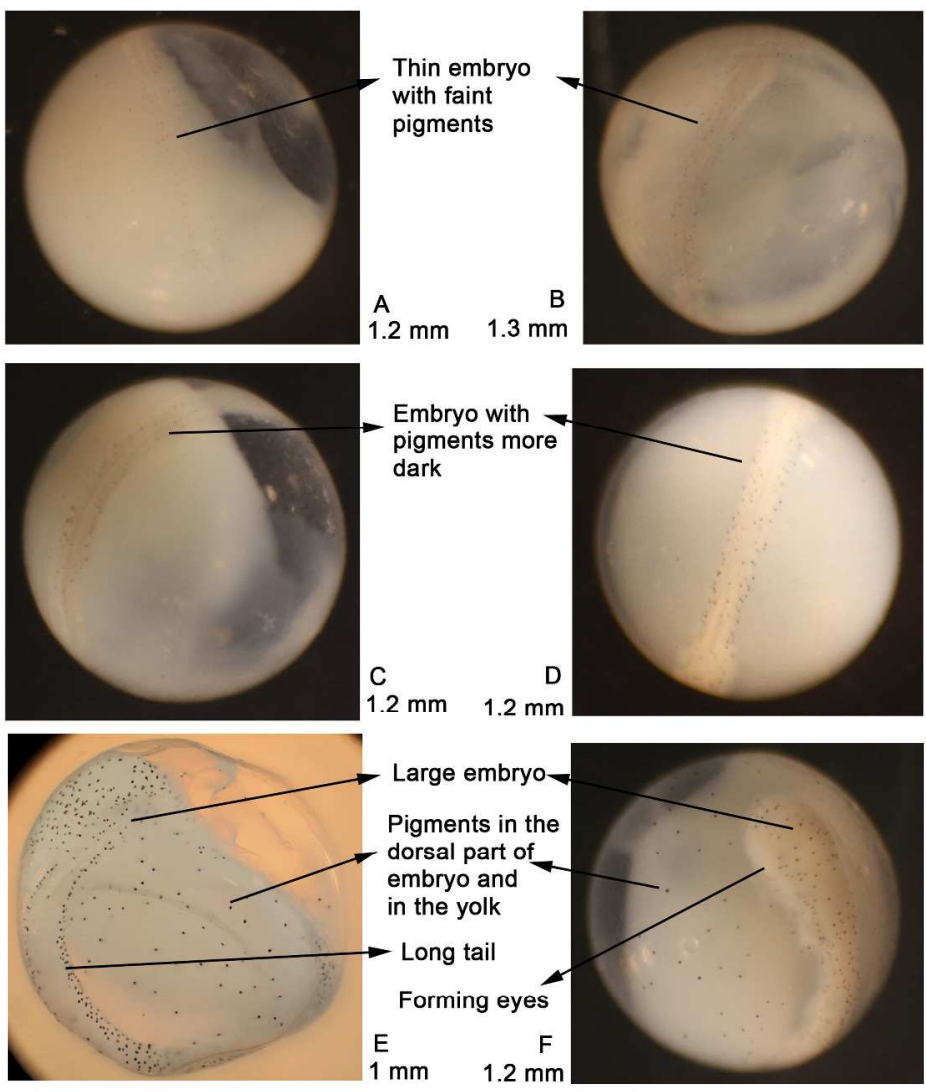

Figure S13.The figures are from the species Remora osteochir, each image shows the eggs with different level of development. Figures A, B, C are from station 83, $\mathrm{D}$ is from the station $84, \mathrm{E}$ is from station 95 and $\mathrm{F}$ from station 90 . 